
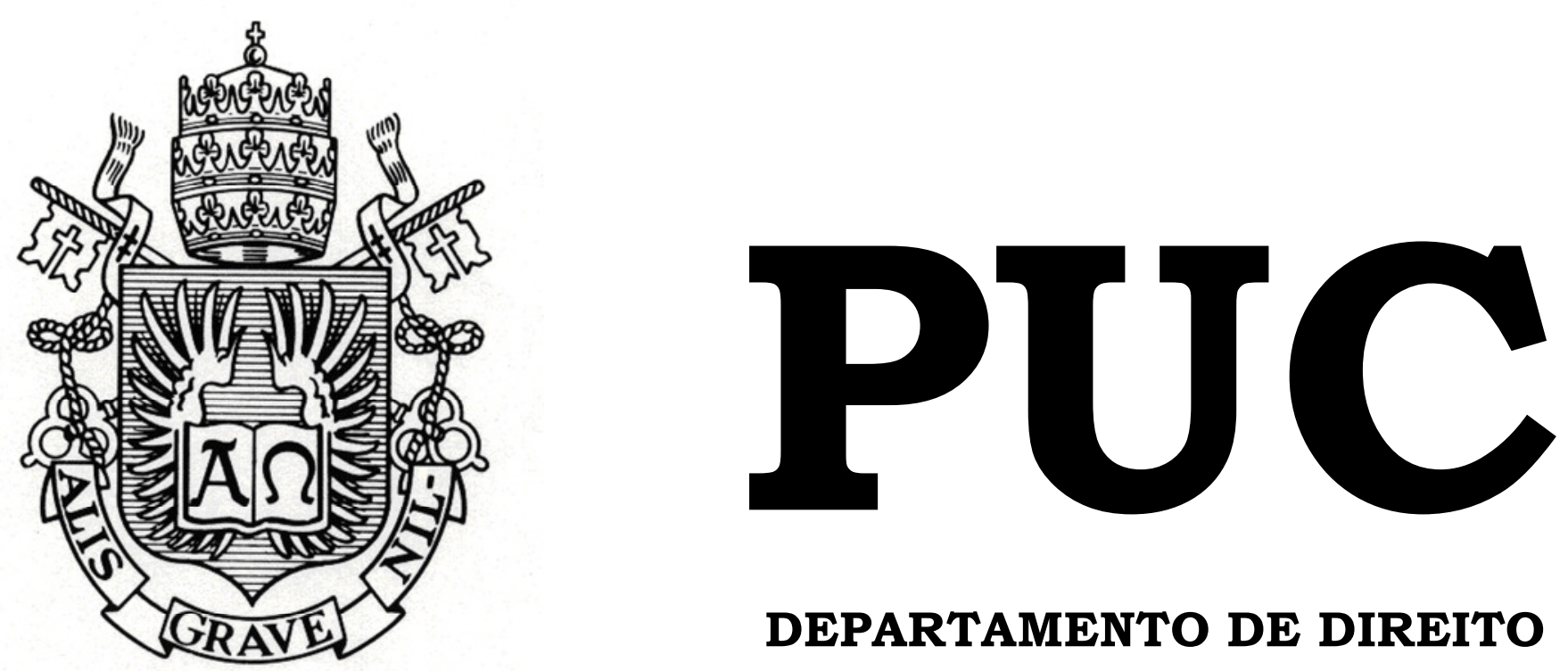

DEPARTAMENTO DE DIREITO

Uma Análise das Mudanças Propostas no Setor de Gás Natural no Brasil

por

PEDRO ÍCARO LOPES VARGAS

ORIENTADORA: Flávia Limmer

2017.2

PONTIFÍCIA UNIVERSIDADE CATÓLICA DO RIO DE JANEIRO

RUA MARQUÊS DE SÃO VICENTE, 225 - CEP 22453-900

RIO DE JANEIRO - BRASIL

\title{
Uma Análise das Mudanças Propostas no Setor de Gás Natural no Brasil
}




\title{
PEDRO ÍCARO LOPES VARGAS
}

\begin{abstract}
Monografia apresentada ao
Departamento de Direito da Pontifícia Universidade Católica do Rio de Janeiro (PUC-Rio) para a obtenção do Título de Bacharel em Direito.
\end{abstract}

Orientadora: Flávia Limmer

\section{2}


Dedico essa monografia aos meus pais, Edna Ferreira Lopes Vargas e José Domingos Vargas. Tudo o que sou, eu devo a Vocês.

Dedico também ao meu avô, Laélio Lopes. "Naquela mesa está faltando ele, e a saudade dele está doendo em mim". 


\section{AGRADECIMENTOS}

Aos meus pais, Edna Ferreira Lopes Vargas e José Domingos Vargas, Aos meus colegas e ex-colegas do Pinheiro Neto Advogados, À minha orientadora, Flávia Limmer.

Obrigado pelo carinho, ajuda e atenção. 


\section{RESUMO}

O presente trabalho busca analisar o setor de gás natural no Brasil, tratando da cadeia do gás natural no país, da legislação e regulamentação principal, da importância do gás natural em uma matriz energética diversificada e dos principais desafios do setor de gás natural no Brasil. Além disso, este trabalho busca analisar as principais propostas para a elaboração de um novo arcabouço normativo do setor.

Palavras-chave: Gás Natural; Constituição Federal; Lei do Petróleo; Lei do Gás; Gás Para Crescer.

\section{SUMMARY}

This article aims to analyze the Brazilian natural gas industry in connection with the natural gas chain, the applicable legislation and regulation, the role played by the natural gas in a diversified electric energy matrix as well as the key issues related to the natural gas sector in Brazil. Moreover, this article purports to analyze the main proposals for the preparation of a new regulatory framework to the sector.

Keywords: Natural Gas; Federal Constitution; Brazilian Petroleum Law; Brazilian Natural Gas

Law. 


\section{SUMÁRIO}

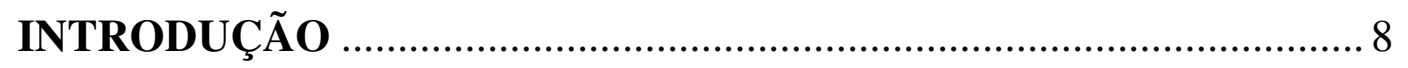

CAPÍTULO 1 - PRECISAMOS FALAR SOBRE GÁS NATURAL ... 10

1.1. Oferta e Demanda de Gás Natural no Brasil e no Mundo .............. 10

1.2. Transição para uma Economia de Baixo CabornoErro! Indicador não definido.

CAPÍTULO 2 - ARCABOUÇO LEGISLATIVO DE REGULATÓRIO

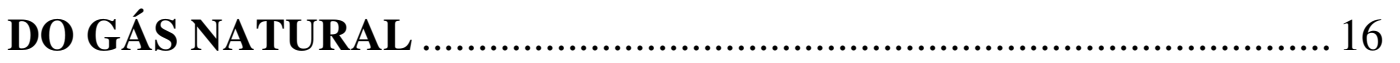

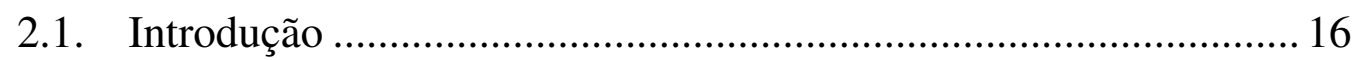

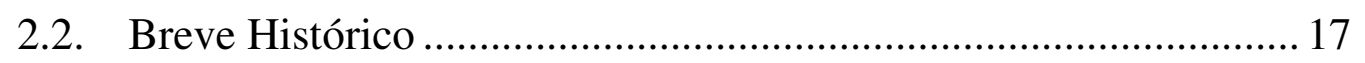

2.3. Constituição Federal e a Emenda Constitucional n 9/1995 ....Erro! Indicador não definido.

2.4. Lei do Petróleo

2.4.1. Conselho Nacional de Política Energética - CNPE 22

2.4.2. Agência Nacional do Petróleo, Gás Natural e Biocombustíveis ANP 24

2.5. Lei do Gás e a Cadeia do Gás Natural 27

CAPÍTULO 3 - GÁS PARA CRESCER, PRINCIPAIS CRÍTICAS AO SETOR DO GÁS NATURAL E O NOVO MARCO REGULATÓRIO

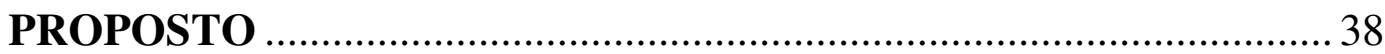

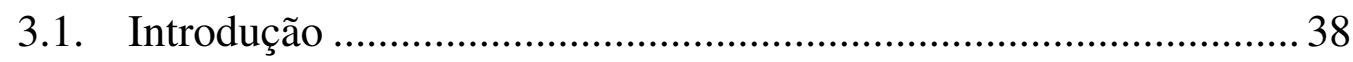

3.2. Gás Para Crescer e as Principais Críticas ao Setor .......................... 36

3.3. Novo Marco Regulatório do Gás Natural ........................................43

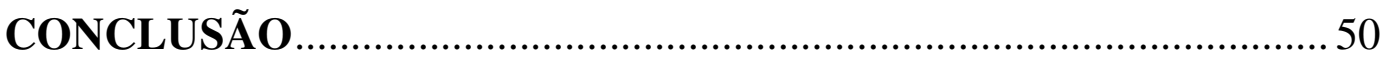

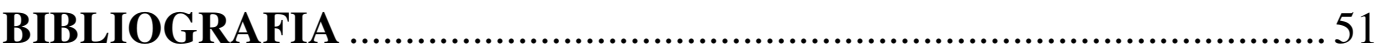




\section{LISTA DE ABREVIAÇÕES}

ABRACE- Associação Brasileira de Grandes Consumidores Industriais de Energia e de Consumidores Livres

ANP - Agência Nacional do Petróleo, Gás Natural e

Biocombustíveis

CME - Comissão de Minas e Energia

CNI - Confederação Nacional da Indústria

CNPE - $\quad$ Conselho Nacional de Política Energética

CT-GN- Comitê Técnico para o Desenvolvimento da Indústria do Gás

Natural

EPE - $\quad$ Empresa de Pesquisa Energética

GASBOL- Gasoduto Bolívia-Brasil

GNL - Gás Natural Liquefeito

GNV - Gás Natural Veicular

MME - $\quad$ Ministério de Minas e Energia

OECD- Organização para a Cooperação e Desenvolvimento

Económico

ONS - Operador Nacional do Sistema Elétrico

PDE 2024- Plano Decenal de Expansão de Energia 2024

PPP - Parceria Público Privada

UPGNs- Unidades de Processamento de Gás Natural 


\section{INTRODUÇÃO}

O desenvolvimento da indústria de Gás Natural no Brasil sempre esteve atrelado ao tema petróleo e ao desempenho e desenvolvimento da estatal Petróleo Brasileiro S.A. - Petrobras, empresa com participação decisiva em todos os elos da cadeia do Gás Natural.

Até metade dos anos 90 o monopólio da Petrobras encontrava bases legais na própria Constituição Federal, por meio da antiga redação conferida ao artigo 177. Somente com o advento da Emenda Constitucional $\mathrm{n}^{\circ}$ 9, datada de 9 de novembro de 1995, na qual se alterou o referido artigo, é que foi dado início a um processo de "flexibilização" do monopólio da empresa no setor ${ }^{1}$.

Objetivando implementar a referida flexibilização, posteriormente vieram as Leis $\mathrm{n}^{\circ} 9.478$, de 6 agosto de 1997, e $\mathrm{n}^{\circ} 11.909$, de março de 2009, regulamentada no ano seguinte pelo Decreto $\mathrm{n}^{\circ} 7.382$, também conhecidas, respectivamente, como "Lei do Petróleo" e "Lei do Gás".

Somam-se às referidas leis todo o arcabouço regulatório da Agência Nacional do Petróleo, Gás Natural e Biocombustíveis - ANP, bem como as diretrizes elaboradas pelo Ministério de Minas e Energia - MME, sobretudo através do Conselho Nacional de Política Energética - CNPE, que resultam em importante regulamentação do setor de Gás Natural no Brasil.

Apesar da consolidação do referido arcabouço normativo, passaramse 22 anos desde a concretização da Emenda Constitucional n ${ }^{\circ} 9$ e, não obstante o aumento significativo na produção de Gás Natural no Brasil, o setor de Gás Natural no Brasil ainda requer avanços importantes no aumento da competição e diversidade de agentes na cadeia do gás.

Para tal, fatores como (i) o elevado nível de endividamento experimentado pela Petrobras nos últimos anos, que resultou em importantes desinvestimentos na indústria de Gás Natural e energia, (ii) a

\footnotetext{
${ }^{1}<$ http://www.mme.gov.br/documents/10584/4006960/0+G\%C3\%A1s+para+Crescer_Relat\%C3\% B3rio+T\%C3\%A9cnico.pdf/92738252-2868-4394-a9fc-b6f4fd9e6bc7>.

Acesso em: 15 de out. de 2017
} 
percepção do Gás Natural como fonte energética de transição para uma economia de baixo carbono, (iii) o possível desenvolvimento do gás do Présal na próxima década, e (iv) a penetração de renováveis no setor elétrico para suprir as dificuldades hídricas, aumentando a necessidade de termelétricas no sistema, somam-se na constituição de um cenário favorável para a entrada de novos investimentos e agentes na cadeia do Gás Natural no Brasil.

Atento a todos esses fatores, o MME lançou em 24 de junho de 2016 a iniciativa "Gás Para Crescer", com o objetivo de estruturar uma reformar no setor através da proposição de medidas concretas de aprimoramento do arcabouço normativo, trazendo para a discussão diversos agentes do mercado.

Em seguimento à referida iniciativa e discussões, foi apresentado no dia 16 de outubro de 2017, em reunião da Comissão de Minas e Energia (CME) da Câmara dos Deputados ${ }^{2}$, o substitutivo ao até então pouco prestigiado projeto de Lei 6.407/2013, que dispõe sobre medidas para fomentar a Indústria de Gás Natural, estabelecendo as novas diretrizes para o setor de gás, por meio da incorporação de propostas e conceitos do Gás para Crescer, e propondo a revogação da Lei do Gás.

Este trabalho tem como objetivo analisar os principais desafios do setor de Gás Natural no Brasil, bem como as principais propostas para a elaboração do novo arcabouço normativo do setor.

\footnotetext{
${ }^{2}<$ http://terciotti.com.br/news/substitutivo-do-pl-do-gas-e-finalizado-e-ja-pode-recebercontribuicoes/>.

Acesso em: 20 de out. 2017
} 


\title{
CAPÍTULO 1 - PRECISAMOS FALAR SOBRE GÁS NATURAL
}

\subsection{Oferta e Demanda de Gás Natural no Brasil e no Mundo}

Conforme definido no artigo $2^{\circ}$, XIV da Lei do Gás, entende-se por Gás Natural ou simplesmente Gás ${ }^{3}$ :

\begin{abstract}
"XIV. Gás Natural ou Gás: todo hidrocarboneto que permaneça em estado gasoso nas condições atmosféricas normais, extraído diretamente a partir de reservatórios petrolíferos ou gaseíferos, cuja composição poderá conter gases úmidos, secos e residuais"
\end{abstract}

Por conta de suas características físico-químicas sucintamente destacadas na legislação acima, o Gás Natural é o combustível fóssil mais limpo e eficiente do mundo, e pode ser produzido tanto de forma associada ao petróleo quanto de forma independente, os chamados "gás associado" e "gás não-associado", respectivamente 4 .

$\mathrm{Na}$ busca pela melhor utilização das referidas características em favor da sociedade, os avanços tecnológicos experimentados nas últimas décadas possibilitam ao Gás Natural ser ofertado em diferentes ramos da encomia, tanto para uso residencial, quanto no comércio, nos transportes (Gás Natural Veicular - GNV), no setor industrial bem como para fins de geração de energia elétrica.

Tais avanços refletem-se nos números. No cenário mundial, os dados também apontam para um crescimento relevante na participação do Gás Natural na matriz energética. Até o ano de 2040, o consumo de Gás Natural aumentará de maneira considerável nos países membros da Organização para a Cooperação e Desenvolvimento Económico - OECD, e de maneira

\footnotetext{
3 <http://www.planalto.gov.br/ccivil_03/_Ato2007-2010/2009/Lei/L11909.htm>. Acesso em: 22 de out. 2017

${ }^{4}$ Carlos Quintella, Camilo Muñoz, Ieda Gomes, Lavinia Hollanda. Cadernos FGV Energia, Novembro 2014, Ano 1, n 2, ISSN 2358 - 5277. p. 14.
} 
ainda mais acentuada nos países não membros, como China e Oriente Médio ${ }^{5}$.

As projeções para o Gás Natural apresentam-se de maneira inversamente proporcional às projeções para os demais combustíveis fósseis, conforme evidenciado na figura abaixo:

Figura 1: Consumo Mundial de Gás Natural

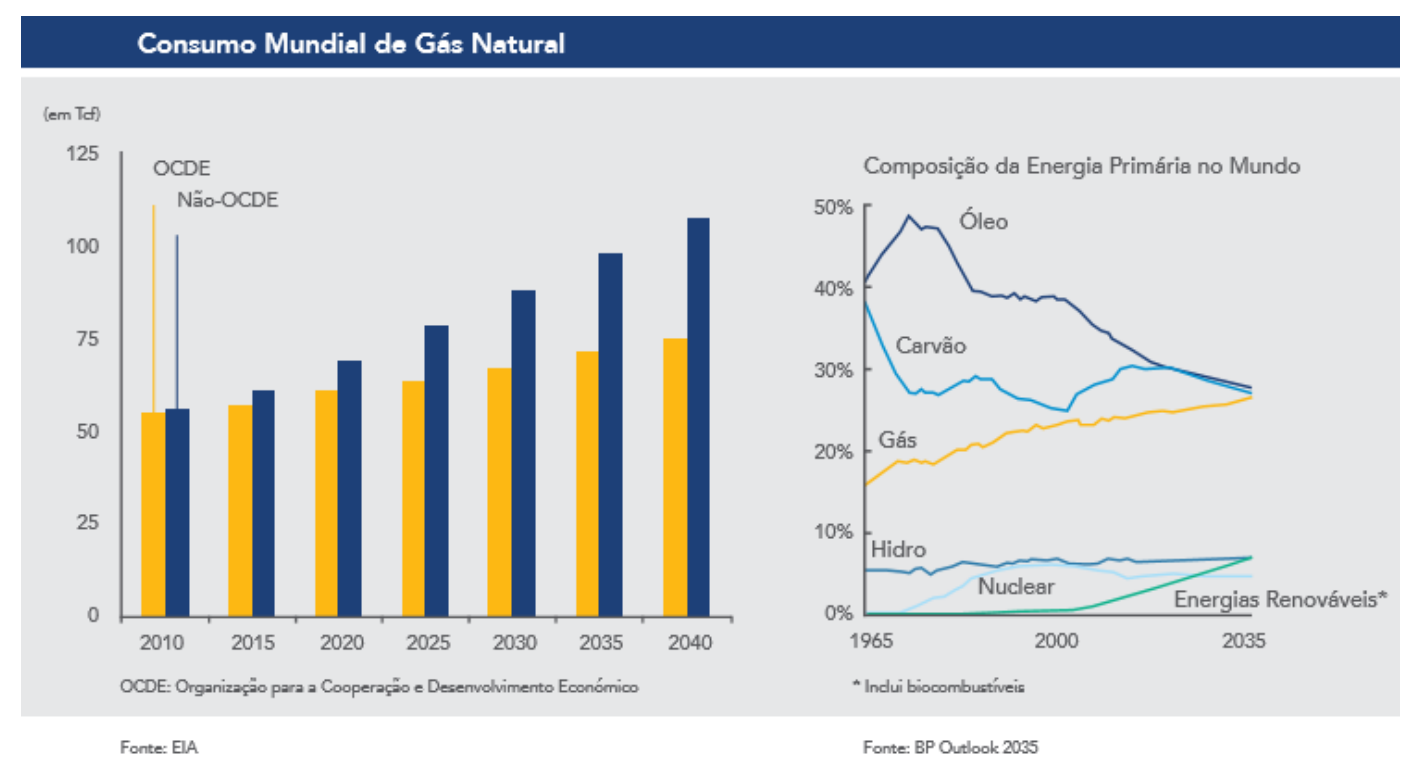

Fonte: GOMES, Ieda; HOLLANDA, Lavinia; MUÑOZ, Camilo; QUINTELLA, Carlos. Cadernos FGV Energia. Novembro 2014, Ano 1, n 2, ISSN $2358-5277$.

Com relação ao Brasil, a participação do Gás Natural na matriz energética brasileira, que era de aproximadamente $2,7 \%$ em 1987, teve crescimento significativo para $10,6 \%$ em 2011, e projeta-se um crescimento para aproximadamente 14,4\% em 2020, segundo dados da Empresa de Pesquisa Energética $-\mathrm{EPE}^{6}$. Conforme apresentado pela empresa de pesquisa no Plano Decenal de Expansão de Energia 2024 - PDE 20247 , a

\footnotetext{
${ }_{5}^{5}$ Carlos Quintella, Camilo Muñoz, Ieda Gomes, Lavinia Hollanda. Cadernos FGV Energia, Novembro 2014, Ano 1, n 2, ISSN 2358 - 5277. p. 21.

${ }^{6}$ MARQUES, Fernando; PEREIRA, Sergio. Gás natural e transição para uma economia de baixo carbono. 1 ed. Rio de Janeiro: Synergia, 2015. p. 120.

${ }^{7}<$ http://www.epe.gov.br/PDEE/Relat\%C3\%B3rio\%20Final\%20do\%20PDE\%202024.pdf>. Acesso em: 19 de out. 2017
} 
demanda de Gás Natural no Brasil poderá aumentar de $108 \mathrm{MMm}^{3 /}$ dia, em 2015, para $171 \mathrm{MMm}^{3 /}$ dia em 2024, sendo que grande parte desse crescimento estaria associado ao aumento de termelétricas de Gás Natural no país.

O referido crescimento na participação do Gás Natural na matriz brasileira foi acompanhado de um importante aumento na sua produção. De acordo com a Associação Brasileira de Grandes Consumidores Industriais de Energia e de Consumidores Livres - ABRACE e a Confederação Nacional da Indústria - CNI, a produção doméstica de Gás Natural praticamente dobrou entre 2005 e $2015^{8}$, conforme gráfico abaixo:

Figura 2: Evolução da Produção de Gás Natural no Brasil

Gráfico 1 - Evoluçāo da Produçāo de Gás Natural no Brasil

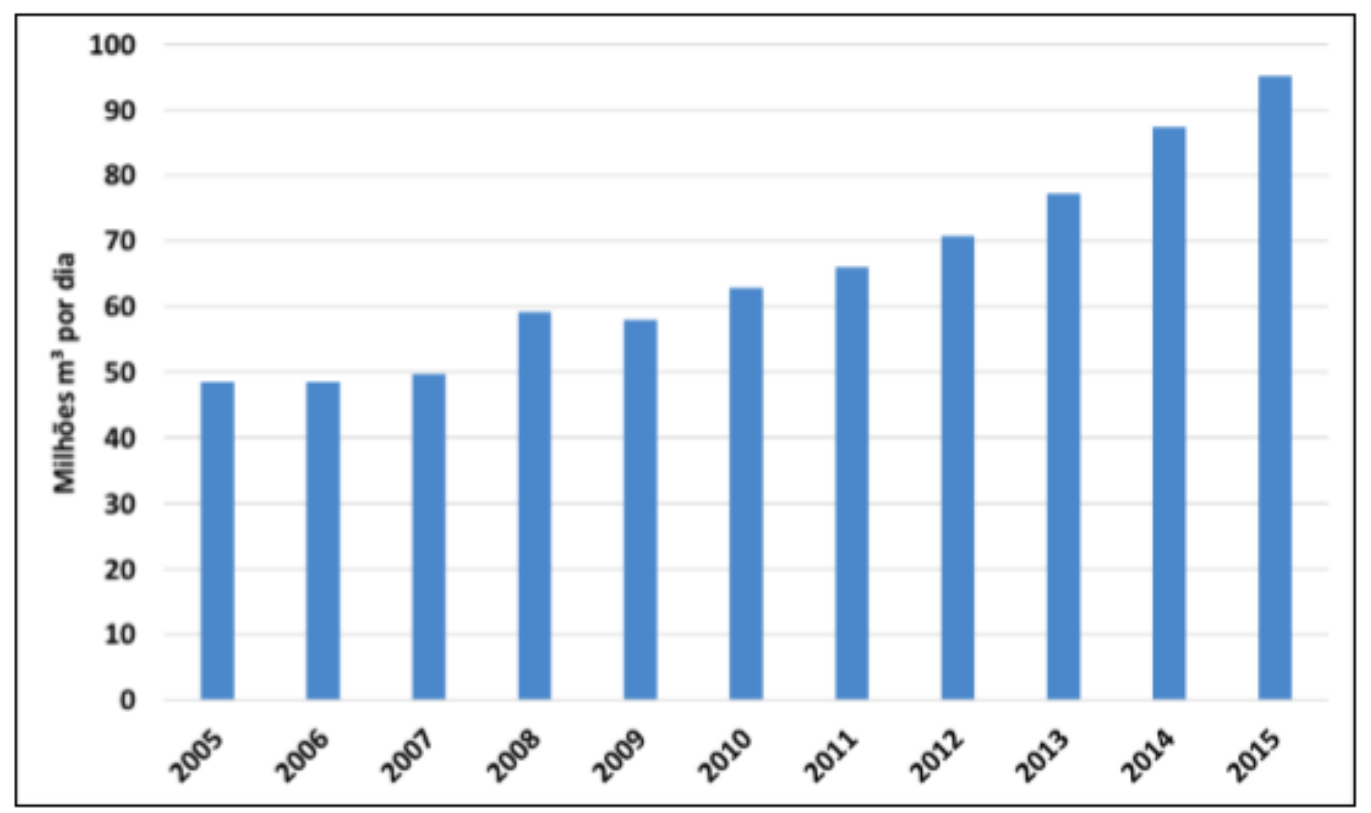

Fonte: Elaboração própria com base em dados da ANP.

Fonte: Confederação Nacional da Indústria. Reestruturação do setor de gás natural: uma agenda regulatória - Brasília: CNI, 2016.

Entretanto, quando destrinchamos nossa produção doméstica observamos que seu crescimento não se traduz em um mercado maduro e

\footnotetext{
${ }^{8}$ Confederação Nacional da Indústria. Reestruturação do setor de gás natural: uma agenda
} regulatória - Brasília: CNI, 2016. p. 23. 
competitivo de Gás Natural. A produção da Petrobras corresponde aproximadamente a $81 \%$ da produção total de Gás Natural brasileira (majoritariamente de gás associado ${ }^{9}$ ), e cerca de outras 35 empresas produzem os $19 \%$ restantes, sendo que praticamente todas essas empresas vendem sua produção para a própria Petrobras, resultando em um setor extremamente dependente dos investimentos da estatal ${ }^{10}$.

Além disso, tal crescimento não foi suficiente para reduzir o alto percentual de gás importado consumido no Brasil. No mesmo intervalo de 10 anos ilustrado acima, as importações de Gás Natural da Bolívia, através do Gasoduto Bolívia-Brasil - GASBOL ${ }^{11}$, bem como via Gás Natural Liquefeito - GNL ${ }^{12}$ importado com o objetivo de suprir os picos de demanda termelétrica resultantes da escassez hidrológica experimentada no país nos últimos anos, perceberam aumento significativo atingindo $53 \%$ da oferta total no Brasil em $2014^{13}$, conforme demonstrado no gráfico abaixo:

\footnotetext{
${ }^{9}$ Conforme descrição no sítio da ANP: "O gás associado é aquele que, no reservatório geológico, se encontra dissolvido no petróleo ou sob a forma de uma capa de gás. Neste caso, normalmente privilegia-se a produção inicial do óleo, utilizando-se o gás para manter a pressão do reservatório. O gás não-associado é aquele que está livre do óleo e da água no reservatório; sua concentração é predominante na camada rochosa, permitindo a produção basicamente de gás natural."

10 Confederação Nacional da Indústria. Reestruturação do setor de gás natural: uma agenda regulatória - Brasília: CNI, 2016. p. 27.

${ }^{11}$ Gasoduto Bolívia-Brasil transporta grandes volumes de gás natural proveniente da Bolívia para o Brasil.

${ }^{12}$ GNL é o gás natural liquefeito por meio da redução da sua temperatura. Trata-se de opção tecnológica para o transporte de gás entre regiões onde não infraestrutura disponível de gasodutos.

${ }^{13}$ Confederação Nacional da Indústria. Reestruturação do setor de gás natural: uma agenda regulatória - Brasília: CNI, 2016. p. 25.
} 
Figura 3: Evolução da Oferta de Gás Natural no Brasil

Gráfico 2 - Evolução da Oferta de Gás Natural no Brasil

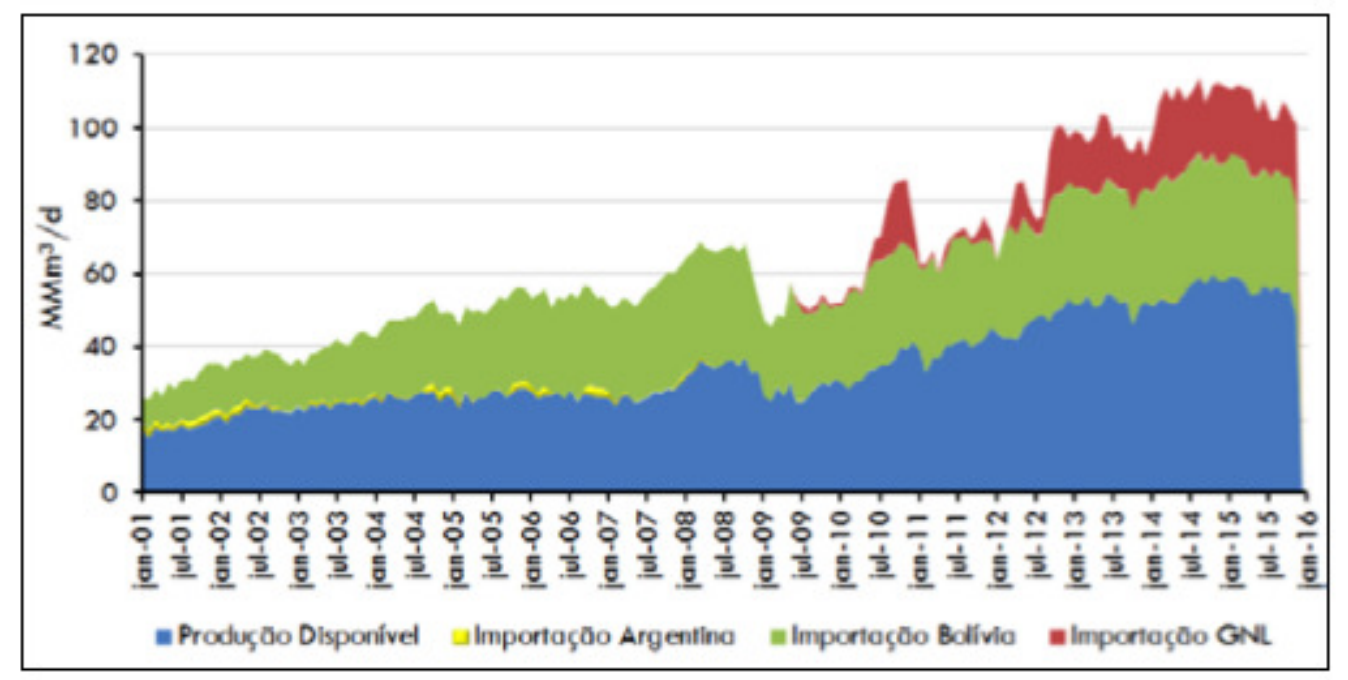

Fonte: Elaboração própria a partir de dados da ANP e do MME

Fonte: Confederação Nacional da Indústria. Reestruturação do setor de gás natural: uma agenda regulatória - Brasília: CNI, 2016.

Como principais problemas decorrentes da alta dependência de Gás Natural importado no setor, destacam-se: (i) o elevado custo do GNL importado, que chega a preços $50 \%$ superiores aos preços do Gás Natural nacional ou importado da Bolívia ${ }^{14}$; (ii) a perda de competitividade da indústria nacional devido ao custo elevado do Gás Natural; e (iii) as incertezas com relação à capacidade de abastecimento de Gás Natural da Bolívia nos próximos anos, cujos investimentos em exploração encontramse estagnados.

Ante as necessidades e desafios expostos, não restam dúvidas quanto a relevância de se discutir Gás Natural no Brasil com o objetivo de construirmos uma agenda positiva para o setor.

${ }^{14}$ Carlos Quintella, Camilo Muñoz, Ieda Gomes, Lavinia Hollanda. Cadernos FGV Energia, Novembro 2014, Ano 1, n 2, ISSN 2358 - 5277. p. 9. 


\subsection{Transição para Uma Economia de Baixo Carbono}

Conforme mencionado anteriormente, o Gás Natural é fonte de energia limpa e possui aplicação em diversos setores da economia, como por exemplo no consumo residencial, comercial, industrial, nos transportes, bem como para fins de geração de energia elétrica.

Apesar de pertencer ao grupo dos combustíveis fósseis, principais responsáveis pela elevação na emissão de gases de efeito estufa, o Gás Natural emite cerca de $50 \%$ menos $\mathrm{CO}_{2}$ do que o carvão e cerca de $40 \%$ menos $\mathrm{CO}_{2}$ do que o petróleo, além de emitir menos compostos de enxofre e particulados devido ao seu grau de pureza e queima limpa ${ }^{15}$.

Mesmo sendo menos poluente que os demais combustíveis fosseis, o Gás Natural é considerado um combustível de elevado poder calorífico com alto rendimento, e tais características técnicas se refletem no aumento significativo na sua produção e consumo no mundo, conforme detalhado anteriormente.

Durante décadas, entretanto, o Gás Natural foi considerado um subproduto do petróleo por possuir menor densidade energética e poder calorífico do que este, o que acarretava em custos mais elevados no seu armazenamento e transporte, sendo-lhe conferido por muito tempo tratamento secundário tanto no plano econômico quanto do ponto de vista jurídico.

Contudo, as inovações tecnológicas ocorridas a partir da segunda metade do século 20, que diminuíram o custo da produção do Gás Natural, associadas ao crescimento da demanda energética mundial, resultante do crescimento populacional ${ }^{16}$, e ao crescimento da conscientização ambiental, resultaram na superação de muitos dos obstáculos que impediam uma maior penetração do Gás Natural na matriz energética mundial ${ }^{17}$.

\footnotetext{
${ }^{15}$ MARQUES, Fernando; PEREIRA, Sergio. Gás natural e transição para uma economia de baixo carbono. 1 ed. Rio de Janeiro: Synergia, 2015. p. 23.

${ }^{16}<$ http://www.prb.org/Publications/Lesson-Plans/HumanPopulation/PopulationGrowth.aspx $>$. Acesso em: 21 de out. de 2017

${ }^{17}$ ROSADO, Marilda. Direito do petróleo. 3 ed. Rio de Janeiro: Renovar, 2014. p. 591.
} 
Além de todas as vantagens anteriormente mencionadas, o Gás Natural possuí importante caráter de complementariedade na matriz energética brasileira. Em outras palavras, as termelétricas movidas a Gás Natural complementam nossas usinas hidrelétricas durante os períodos de escassez hídrica bem como compensam a produção intermitente eólica e solar $^{18}$.

Somados, tais fatores fazem do Gás Natural o substituto natural do petróleo, cujas reservas e consumo tendem a diminuir nas próximas décadas, sendo apontado como o combustível capaz de garantir nossa transição para uma economia de baixo carbono.

\footnotetext{
${ }^{18}$ MARQUES, Fernando; PEREIRA, Sergio. Gás natural e transição para uma economia de baixo carbono. 1 ed. Rio de Janeiro: Synergia, 2015. p. 154. 


\section{CAPÍTULO 2- ARCABOUÇO LEGISLATIVO E REGULATÓRIO DO GÁS NATURAL}

\subsection{Introdução}

Conforme mencionado anteriormente, o desenvolvimento da indústria de Gás Natural no Brasil sempre esteve atrelado às discussões relativas ao petróleo e ao desempenho da Petrobras. A referida estatal exercia o monopólio da União com base na antiga redação conferida ao artigo 177 da Constituição Federal, que só foi alterado com o advento da Emenda Constitucional $\mathrm{n}^{\circ}$ 9/1995, iniciando um processo de "flexibilização" do monopólio da empresa no setor.

No intuito de viabilizar tal processo, dois anos após a publicação da referida emenda o legislador aprovou a Lei do Petróleo e, 12 anos após a aprovação da referida lei, foi criada a Lei do Gás com a finalidade de exercer a função de marco regulatório para o setor, conforme melhor tratado a seguir.

Passados 22 anos desde o início do processo de flexibilização, entretanto, a Petrobras ainda figura como agente dominante do setor de Gás Natural no Brasil, sendo responsável pela produção de $81 \%$ do gás nacional, bem como proprietária da maior parte dos ativos de escoamento, transporte e tratamento, além de possuir participação em 20 das 27 distribuidoras de gás do país ${ }^{19}$, evidenciando a incapacidade da referida legislação em atrair de forma concomitante investimentos e novos agentes para o setor.

Neste capítulo trataremos do arcabouço legislativo e regulatório do Gás Natural no Brasil, bem como da cadeia do Gás Natural.

\footnotetext{
${ }^{19}$ Confederação Nacional da Indústria. Reestruturação do setor de gás natural: uma agenda regulatória - Brasília: CNI, 2016. p. 27.
} 


\subsection{Breve Histórico}

Com o aumento da importância estratégica do setor de petróleo e gás na primeira metade do século XX, bem como baseado nos rumores relativos à existência de petróleo em solo nacional, no dia 29 de abril de 1938 Getúlio Vargas editou o Decreto-lei $\mathrm{n}^{\circ} 395$, primeira norma a tratar especificamente do abastecimento nacional de petróleo ${ }^{20}$.

No referido decreto estabeleceu-se que as jazidas de petróleo eram consideradas "patrimônio da nação" e o abastecimento nacional de petróleo ganhou status de utilidade pública ${ }^{21}$, com base no antigo Código de Minas (Decreto $\mathrm{n}^{\circ} 24.642$ de 10 de julho de 1934), desvinculando a propriedade imobiliária das jazidas. Além disso, o referido decreto tratou da nacionalização do refino e criou o Conselho Nacional do Petróleo, órgão subordinado ao Presidente da República que posteriormente inspirou a criação do CNPE.

Posteriormente, com o crescimento do movimento "o petróleo é nosso", Getúlio Vargas editou em 3 de outubro de 1953 a Lei n ${ }^{\circ} 2004^{22}$, instituindo oficialmente o monopólio da União sobre "a pesquisa e a lavra das jazidas de petróleo e outros hidrocarbonetos fluidos", bem como sobre as atividades de refino e transporte ${ }^{23}$. Além disso, por meio da referida legislação foi criada a Petrobras, incumbida de exercer o monopólio da União.

Por fim, em 1988 o monopólio da União sobre a pesquisa, importação, exportação, lavra, refino e transporte do petróleo, Gás Natural e derivados ganha status de norma constitucional com a promulgação da Constituição Federal, conforme melhor tratado a seguir.

\footnotetext{
${ }^{20}$ NETO, Artur Watt. Petróleo, gás natural e biocombustíveis: doutrina, jurisprudência e legislação. 1 ed. São Paulo: Saraiva, 2014. p. 23.

21 < http://www.planalto.gov.br/ccivil_03/Decreto-Lei/1937-1946/Del0395.htm>.

Acesso em: 23 de out. de 2017

$22<$ http://www.planalto.gov.br/ccivil_03/LEIS/L2004.htm>.

Acesso em: 23 de out. de 2017

${ }^{23}$ NETO, Artur Watt. Petróleo, gás natural e biocombustíveis: doutrina, jurisprudência e legislação. 1 ed. São Paulo: Saraiva, 2014. p. 24.
} 


\subsection{Constituição Federal e a Emenda Constitucional $n^{\circ} 9 / 1995$}

Como tratado anteriormente, foi a partir da promulgação da Constituição Federal de 1988 que o monopólio da União sobre as seguintes atividades relativas ao petróleo, Gás Natural e derivados do petróleo foi constitucionalizado, na forma do caput do artigo $177^{24}$.

“Art. 177. Constituem monopólio da União:

I - a pesquisa e a lavra das jazidas de petróleo e gás natural e outros hidrocarbonetos fluidos;

II - a refinação do petróleo nacional ou estrangeiro;

III - a importação e exportação dos produtos e derivados básicos resultantes das atividades previstas nos incisos anteriores;

IV - o transporte marítimo do petróleo bruto de origem nacional ou de derivados básicos de petróleo produzidos no País, bem assim o transporte, por meio de conduto, de petróleo bruto, seus derivados e gás natural de qualquer origem;

$\mathrm{V}$ - a pesquisa, a lavra, o enriquecimento, o reprocessamento, a industrialização e o comércio de minérios e minerais nucleares e seus derivados.

$\mathrm{V}$ - a pesquisa, a lavra, o enriquecimento, o reprocessamento, a industrialização e o comércio de minérios e minerais nucleares e seus derivados, com exceção dos radioisótopos cuja produção, comercialização e utilização poderão ser autorizadas sob regime de permissão, conforme as alíneas b e c do inciso XXIII do caput do art. 21 desta Constituição Federal."

Além disso, a antiga redação conferida ao parágrafo primeiro do artigo 177 vedava expressamente a cessão ou concessão pela União de qualquer tipo de participação, em espécie ou em valor, na exploração de jazidas de petróleo e Gás Natural ${ }^{25}$.

Somente em 1995, mediante contexto de diminuição da participação do Estado promovida pelo Governo Federal através da manutenção de políticas como o Programa Nacional de Desestatização, criado pela Medida Provisória $\mathrm{n}^{\circ} 155$, de março de 1990, convertida na Lei $\mathrm{n}^{\circ} 8031$, de 12 de abril de 1990, e posteriormente substituída pela Lei $\mathrm{n}^{\circ} 9491$, de 9 de

\footnotetext{
${ }^{24}<$ http://www.planalto.gov.br/ccivil_03/Constituicao/Constituicao.htm> Acesso em: 23 de out. de 2017

${ }^{25}$ Antiga redação do parágrafo primeiro do artigo 177 da Constituição Federal de 1988: "O monopólio previsto neste artigo inclui os riscos e resultados decorrentes das atividades nele mencionadas, sendo vedado à União ceder ou conceder qualquer tipo de participação, em espécie ou em valor, na exploração de jazidas de petróleo ou gás natural, ressalvado o disposto no art. $20, \S 1^{o} . "$
} 
setembro de 1997, decidiu-se acabar com a vedação expressa contida no antigo parágrafo primeiro do artigo 177 por meio da promulgação da Emenda Constitucional $\mathrm{n}^{\circ}$ 9, de 9 de novembro de $1995^{26}$, dando início ao anteriormente mencionado processo de "flexibilização" do monopólio da União via Petrobras, conforme exposição de motivos da Proposta de Emenda Constitucional $n^{\circ} 6 / 95$, que posteriormente resultou na Emenda Constitucional $\mathrm{n}^{\circ}$ 9/1995: “a atração de capitais privados para determinadas atividades em que se requer a expansão dos investimentos em volume insuscetível de financiamento exclusivo por parte da Petrobras." 27.

Desse modo, o parágrafo primeiro do artigo 177 da Constituição Federal de 1988 passou a figurar com a seguinte redação, possibilitando a contratação de empresas estatais ou privadas para o exercício das atividades da indústria do petróleo e Gás Natural:

“§ $1^{\circ}$ A União poderá contratar com empresas estatais ou privadas a realização das atividades previstas nos incisos I a IV deste artigo observadas as condições estabelecidas em lei."

Ainda com relação aos artigos previstos na Constituição Federal de 1988 relativos ao setor de Gás Natural, cumpre destacar o parágrafo segundo do artigo 25, que atribuiu aos Estados a exploração dos serviços locais de gás canalizado, de forma direta ou mediante concessão ${ }^{28}$, conforme melhor destrinchado abaixo.

\footnotetext{
${ }^{26}<$ http://www.planalto.gov.br/ccivil_03/Constituicao/Emendas/Emc/emc09.htm\#art3>. Acesso em: 23 de out. de 2017

$27<$ http://www.mme.gov.br/documents/10584/4006960/0+G\%C3\%A1s+para+Crescer_Relat\%C3 \%B3rio+T\%C3\%A9cnico.pdf/92738252-2868-4394-a9fc-b6f4fd9e6bc7>. Acesso em: 23 de out. de 2017

${ }^{28}<$ http://www.planalto.gov.br/ccivil_03/Constituicao/Constituicao.htm>.

Acesso em: 23 de out. de 2017
} 


\subsection{Lei do Petróleo}

$\mathrm{Na}$ forma do parágrafo segundo do artigo 177 da Constituição Federal de 1988, também inserido pela Emenda Constitucional n 9/1995, previu-se a criação da Lei do Petróleo:

" $\$ 2^{\circ}$ A lei a que se refere o $\S 1^{\circ}$ disporá sobre:

I - a garantia do fornecimento dos derivados de petróleo em todo o território nacional;

II - as condições de contratação;

III - a estrutura e atribuições do órgão regulador do monopólio da União".

Entretanto, somente dois anos após a edição da emenda a previsão de criação de legislação específica constante no referido artigo foi atendida, mediante publicação em 6 de agosto de 1997 do marco regulatório para a indústria, implementando a flexibilização do monopólio da Petrobras.

Dentre os pontos mais relevantes abordados na Lei do Petróleo, destacam-se: (i) a ratificação da propriedade da União sobre os depósitos de petróleo, Gás Natural e demais hidrocarbonetos ${ }^{29}$; (ii) a previsão do regime de concessão, precedida de licitação, para as atividades de exploração, desenvolvimento e produção ${ }^{30}$, e do regime de autorização para as atividades de transporte, importação e exportação ${ }^{31}$, relacionadas ao petróleo, Gás Natural e demais hidrocarbonetos fluídos; bem como (iii) a criação do CNPE, com objetivo de assessorar o Presidente da República, e da ANP, conforme previsto no inciso III do parágrafo segundo do artigo

\footnotetext{
${ }^{29}$ Artigo $4^{\circ}$ : “Art. $4^{\circ}$ Constituem monopólio da União, nos termos do art. 177 da Constituição Federal, as seguintes atividades: I - a pesquisa e lavra das jazidas de petróleo e gás natural e outros hidrocarbonetos fluidos; II - a refinação de petróleo nacional ou estrangeiro; III - a importação e exportação dos produtos e derivados básicos resultantes das atividades previstas nos incisos anteriores; IV - o transporte marítimo do petróleo bruto de origem nacional ou de derivados básicos de petróleo produzidos no País, bem como o transporte, por meio de conduto, de petróleo bruto, seus derivados e de gás natural.".

${ }^{30}$ Artigo 23: "As atividades de exploração, desenvolvimento e produção de petróleo e de gás natural serão exercidas mediante contratos de concessão, precedidos de licitação, na forma estabelecida nesta Lei, ou sob o regime de partilha de produção nas áreas do pré-sal e nas áreas estratégicas, conforme legislação específica.".

${ }^{31}$ Artigo 60: "Qualquer empresa ou consórcio de empresas que atender ao disposto no art. $5^{\circ}$ poderá receber autorização da ANP para exercer a atividade de importação e exportação de petróleo e seus derivados, de gás natural e condensado.”.
} 
177 acima, exercendo a função de órgão regulador do monopólio da União e fiscalizador de toda a cadeia de combustíveis ${ }^{32}$.

Especificamente com relação ao Gás Natural, excetuadas as atividades de produção e distribuição de Gás Natural em gasodutos de baixa pressão, tratadas como serviço público no âmbito estadual conforme previsto no parágrafo segundo do artigo 25 da Constituição Federal mencionado acima, a Lei do Petróleo conferiu regime de autorização para as atividades de transporte de gás, refinação, processamento, liquefação e regaseificação, nas quais as empresas interessadas em participar da cadeia poderiam pleitear o direito de explorar e construir a infraestrutura aplicável ${ }^{33}$.

Cumpre destacar que o regime de autorização é tradicionalmente dotado de discricionariedade de precariedade, possuindo natureza jurídica constitutiva no sentido de não reconhecer direito subjetivo preexistente ao particular, mas criando direitos e obrigações a partir do ato. Devido à sua discricionariedade, para consentir com o exercício da atividade autorizada a Administração Pública emite um juízo de conveniência e oportunidade. Por ser precário, o ato é revogável a qualquer momento, não surgindo para o particular qualquer direito subjetivo à indenização ${ }^{34}$. Considerando a falta de segurança jurídica conferida por tais características, os investidores não encontraram na Lei do Petróleo o conforto necessário para investir o volume intensivo de capital necessário para algumas das atividades do setor de Gás Natural, como a atividade de transporte.

A Lei do Petróleo estabeleceu também que os referidos direitos de exploração e produção de petróleo e Gás Natural seriam administrados pela ANP, nos termos do seu artigo $21^{35}$ :

\footnotetext{
${ }^{32}$ NETO, Artur Watt. Petróleo, gás natural e biocombustíveis: doutrina, jurisprudência e legislação. 1 ed. São Paulo: Saraiva, 2014. p. 25.

${ }_{33}$ ARAGÃO, Alexandre Santos De. Direito do petróleo e de outras fontes de energia. 1 ed. Rio de Janeiro: Lumen Juris, 2011. p. 460.

${ }^{34}$ ROSADO, Marilda. Direito do petróleo. 3 ed. Rio de Janeiro: Renovar, 2014. p. 598.

${ }^{35}<$ https://www.planalto.gov.br/ccivil_03/Leis/L9478.htm>.

Acesso em: 22 de out. de 2017
} 
“Art. 21. Todos os direitos de exploração e produção de petróleo, de gás natural e de outros hidrocarbonetos fluidos em território nacional, nele compreendidos a parte terrestre, o mar territorial, a plataforma continental e a zona econômica exclusiva, pertencem à União, cabendo sua administração à ANP, ressalvadas as competências de outros órgãos e entidades expressamente estabelecidas em lei.

Do ponto de vista regulatório, os anos que sucederam a publicação da Lei do Petróleo foram de baixo grau de regulação no que tange o setor de Gás Natural, pois a regulamentação aplicável conferia considerável grau de liberdade para as partes acordarem os termos e condições das relações jurídicas que estabeleciam, enquanto a ANP restringia-se ao controle de entrada de novos agentes no setor ${ }^{36}$.

Apesar de ser considerada como um marco regulatório, sobretudo para a indústria do petróleo, a Lei do Petróleo não conseguiu atrair o volume de investimentos privados necessário para garantir o desenvolvimento do setor de Gás Natural.

Nesse sentido, foram apontadas pela ANP como principais carências da referida legislação, na Nota Técnica “Organização da Indústria Brasileira de Gás Natural e Abrangência de Uma Nova Legislação" de 2004, o tratamento generalista dado à atividade de transporte de gás bem como a falta de diretrizes claras quanto à política do setor, tratando o Gás Natural como um subproduto do petróleo ${ }^{37}$ e possibilitando que matérias de grande importância fossem tratadas em atos de natureza regulatória.

O tratamento lacunoso conferido ao Gás Natural pela Lei do Petróleo se reflete nos números. Apenas três dos oitenta e três artigos que compõem a Lei do Petróleo fazem referência ao transporte de Gás Natural ${ }^{38}$ : (i) artigo 56, anteriormente citado, que prevê o regime de autorização para a atividade de transporte de Gás Natural e concede à ANP a responsabilidade pela condução das autorizações; (ii) artigo 58, que estabelece o conceito de livre acesso à infraestrutura de gasodutos, atribuindo à ANP a competência

\footnotetext{
${ }^{36}$ ARAGÃO, Alexandre Santos De. Direito do petróleo e de outras fontes de energia. 1 ed. Rio de Janeiro: Lumen Juris, 2011. p. 461.

${ }^{37}<$ http://www.anp.gov.br/wwwanp/notas-tecnicas $>$.

Acesso em: 24 de out. de 2017

${ }^{38}$ ROSADO, Marilda. Direito do petróleo. 3 ed. Rio de Janeiro: Renovar, 2014. p. 595.
} 
de fixar as tarifas de transporte na ausência de acordo entre as partes contratantes; e (iii) artigo 59, que define as regras de reclassificação dos gasodutos de transferência.

Segundo a ANP, esses gaps aumentaram a "percepção de risco" dos investidores, restando clara a necessidade de criação de um novo marco regulatório para o Gás Natural, que tratasse "adequadamente várias das questões tratadas superficialmente, ou nem mesmo contempladas, na atual Lei do Petróleo".

\subsubsection{Conselho Nacional de Política Energética - CNPE}

Antes de tratarmos da Lei do Gás, é importante tratarmos de dois órgãos criados a partir da Lei do Petróleo e que possuem importância fundamental para o setor de Gás Natural: o CNPE e a ANP.

O CNPE foi criado com inspiração no anteriormente citado Conselho Nacional do Petróleo, criado por Getúlio Vargas em 1938, para atuar como órgão interministerial, com a função de propor ao Presidente da República políticas e medidas para o setor energético nacional ${ }^{39}$.

Nos termos do Decreto ${ }^{\circ} 3520$, de 21 de junho de 2000, integram o CNPE: (i) o Ministro de Minas e Energia; (ii) o Ministro da Ciência e Tecnologia; (iii) o Ministro do Planejamento; (iv) o Ministro da Fazenda; (v) o Ministro de Meio Ambiente; (vi) o Ministro do Desenvolvimento, Indústria e Comércio Exterior; (vii) o Ministro Chefe da Casa Civil; (viii) o Ministro da Integração Nacional; (ix) o Ministro da Agricultura; (x) um representante dos Estados e do Distrito Federal; (xi) um representante da sociedade civil especialista em matéria de energia; (xii) um representante de universidade brasileira especialista em matéria de energia; (xiii) o Secretário-Executivo do Ministério de Minas e Energia; e (xiv) o Presidente da $\mathrm{EPE}^{40}$.

\footnotetext{
39 NETO, Artur Watt. Petróleo, gás natural e biocombustíveis: doutrina, jurisprudência e legislação. 1 ed. São Paulo: Saraiva, 2014. p. 27.

${ }^{40}<$ http://www.planalto.gov.br/ccivil_03/decreto/D3520.htm>.
} 
De acordo com o artigo segundo da Lei do Petróleo ${ }^{41}$, o CNPE possui a atribuição de propor ao Presidente da República políticas nacionais e medidas específicas relacionadas ao setor energético, dentre as quais atingem de forma mais direta e relevante o setor de Gás Natural:

(a) estabelecer diretrizes para os programas de uso do Gás Natural;

(b) estabelecer diretrizes para a importação e exportação, de maneira a atender às necessidades de consumo interno Gás Natural;

(c) estabelecer diretrizes para o uso de Gás Natural como matériaprima em processos produtivos industriais, mediante a regulamentação de condições e critérios específicos, que visem a sua utilização eficiente e compatível com os mercados interno e externos; e

(d) definir a estratégia e a política de desenvolvimento econômico e tecnológico da indústria de petróleo, de Gás Natural, de outros hidrocarbonetos fluidos e de biocombustíveis, bem como da sua cadeia de suprimento.

Apesar de ser um órgão que possui papel meramente propositivo, de modo que não toma decisões, apenas fornece sugestões ao Presidente da República, o CNPE representa um deslocamento na tomada de decisões importantes para o setor energético, pois decisões anteriormente centralizadas na ANP, como por exemplo as definições de blocos que serão objeto de leilões, passaram a ser discutidas no âmbito do conselho e posteriormente submetidas ao Presidente da República, resultando em um aumento da importância do CNPE.

\subsubsection{Agência Nacional do Petróleo, Gás Natural e Biocombustíveis - ANP}

Conforme previsto no inciso III do parágrafo segundo do artigo 177 da Constituição Federal de 1988, acrescido pela Emenda Constitucional ${ }^{\circ}$

\footnotetext{
Acesso em: 24 de out. de 2017

${ }^{41}<$ http://www.planalto.gov.br/ccivil_03/LEIS/L9478.htm>.

Acesso em: 25 de out. de 2017
} 
9/1995, designou-se à Lei do Petróleo dispor sobre a estrutura e atribuições do "órgão regulador do monopólio da União"42. Assim, em 6 de agosto de 1997 foi criada a ANP, órgão submetido ao regime autárquico especial e vinculado ao Ministério de Minas e Energia, incumbido da tarefa de regular a indústria do petróleo e Gás Natural.

Posteriormente a ANP teve sua área de atuação aumentada por meio da edição da Lei $n^{\circ} 11.097$, de 13 de janeiro de 2005, que dispõe sobre a introdução do biodiesel na matriz energética brasileira, acrescentando "Biocombustíveis" ao nome da agência, para que o setor de combustíveis renováveis se tornasse também atribuição da $\mathrm{ANP}^{43}$.

Além disso, com a edição da Lei do Gás a ANP sofreu um reforço nas suas competências relativas ao Gás Natural, inclusive mediante a introdução de modelo de concessão para gasodutos de transporte de gás, conforme melhor tratado a seguir.

Com inspiração no modelo norte-americano de autoridade administrativa independente, atribuiu-se à ANP competência para atuar de forma ampla no mercado regulado. Dentre seus principais poderes destacam-se ${ }^{44}$ :

(a) Poder normativo: poder de edição de normas regulamentadoras que obrigam os agentes econômicos no exercício das atividades reguladas, observadas as disposições legais;

(b) Poder concedente: poder de representação da União na qualidade de poder concedente no regime de concessão para exploração e produção, podendo definir blocos para licitação, realizar a licitação e celebra contratos de concessão;

\footnotetext{
$42<$ http://www.planalto.gov.br/ccivil_03/Constituicao/Constituicao.htm>. Acesso em: 25 de out. de 2017

43 <https://www.planalto.gov.br/ccivil_03/_Ato2004-2006/2005/Lei/L11097.htm>. Acesso em: 23 de out. de 2017

44 NETO, Artur Watt. Petróleo, gás natural e biocombustíveis: doutrina, jurisprudência e legislação. 1 ed. São Paulo: Saraiva, 2014. p. 31.
} 
(c) Poder fiscalizatório: poder de fiscalizar toda a cadeia de petróleo, Gás Natural e demais combustíveis aplicáveis, com a possibilidade de aplicar sanções;

(d) Poder decisório: prerrogativa de decidir em última instância administrativa com relação a matérias de sua competência.

Dentre as atribuições da ANP previstas atualmente na Lei do Petróleo, refletindo sobretudo as alterações conferidas pela Lei do Gás, destacam-se por afetarem de forma mais direta o setor de Gás Natural ${ }^{45}$ : (i) a implementação da política nacional de petróleo, Gás Natural e biocombustíveis; (ii) a elaboração de editais e promoção de licitações para a concessão de exploração, desenvolvimento e produção, por meio da celebração de contratos e fiscalização da execução dos mesmo; (iii) o estabelecimento de critérios para o cálculo de tarifas de transporte dutoviário; (iv) a fiscalização das atividades da indústria do petróleo, Gás Natural e dos biocombustíveis, bem como a aplicação de sanções administrativas e pecuniárias; (v) especificar a qualidade dos derivados de petróleo, Gás Natural, biocombustíveis e seus derivados; (vi) regular e fiscalizar o acesso à capacidade dos gasodutos; (vii) promover, as chamadas públicas para a contratação de capacidade de transporte de Gás Natural, conforme as diretrizes do MME; (viii) registrar os contratos de transporte de Gás Natural e de interconexão entre as instalações de transporte, bem como os contratos de comercialização; (ix) regular e fiscalizar o exercício da atividade de estocagem de Gás Natural; (x) elaborar os editais e promover as licitações destinadas à contratação de concessionários para a exploração das atividades de transporte e de estocagem de Gás Natural, bem como celebrar os contratos de concessão para a prática das referidas atividades; (xi) autorizar a prática de comercialização de gás natural; (xii) articular-se com órgãos reguladores estaduais e ambientais, objetivando

\footnotetext{
${ }^{45}<$ http://www.planalto.gov.br/ccivil_03/LEIS/L9478.htm>. Acesso em: 25 de out. de 2017
} 
compatibilizar e uniformizar as normas aplicáveis à indústria e aos mercados de Gás Natural.

A estrutura organizacional da agência também foi tratada pela Lei do Petróleo, que estabeleceu que a ANP seria dirigida através de regime colegiado por uma Diretoria composta por um Diretor-Geral e quatro Diretores, com mandatos fixos e não coincidentes de quatro anos ${ }^{46}$. A agência conta também com Superintendências e Núcleos de Fiscalização e Informática, nos termos do seu Regimento Interno aprovado por meio da Portaria ANP n ${ }^{\circ}$ 69, de 6 de abril de $2011^{47}$.

\subsection{Lei do Gás e a Cadeia do Gás Natural}

Com o objetivo de preencher as lacunas da Lei do Petróleo relativas ao setor de Gás Natural, bem como objetivando regular o acesso à infraestrutura do setor, incentivar a construção de um mercado concorrencial e a criação de mecanismos de indução e direcionamento dos investimentos privados através de planejamento estatal ${ }^{48}$, em 4 de março de 2009 foi publicada a Lei do Gás, posteriormente regulamentada pelo Decreto $\mathrm{n}^{\circ} 7.382$, de 2 de dezembro de 2010 .

Na opinião dos professores especialistas no setor de Gás Natural Edmar Almeida e Marcelo Ferraro, a Lei do Gás buscou “dar maior racionalidade ao processo de planejamento da expansão da malha de transporte e aumentar a transparência e, consequentemente, a competição entre os diferentes agentes componentes da indústria"49.

No entendimento da professora Maria D’Assunção Costa, a criação da Lei do Gás permitiu melhor elaboração de vários arranjos contratuais entre os importadores, exportadores, comercializadores, distribuidoras e

\footnotetext{
46 NETO, Artur Watt. Petróleo, gás natural e biocombustíveis: doutrina, jurisprudência e legislação. 1 ed. São Paulo: Saraiva, 2014. p. 33.

$47<$ http://nxt.anp.gov.br/NXT/gateway.dll?f=templates\&fn=default.htm\&vid=anp:10.1048/enu>. Acesso em: 23 de out. de 2017

${ }^{48}$ ARAGÃO, Alexandre Santos De. Direito do petróleo e de outras fontes de energia. 1 ed. Rio de Janeiro: Lumen Juris, 2011. p. 462.

${ }^{49}$ ALMEIDA, Edmar; FERRARO, Marcelo. Indústria do gás natural: fundamentos técnicos e econômicos. 1 ed. Rio de Janeiro: Synergia, 2013. p. 260.
} 
consumidores livres, através de contratos de regaseificação, transporte, compressão e outros ${ }^{50}$.

Para tal, a referida lei tratou tanto das atividades previstas no anteriormente citado artigo 177 da Constituição Federal com relação ao setor de Gás Natural, que são o transporte de Gás Natural através de condutos bem como a importação e exportação do combustível, quanto das atividades de tratamento, processamento, estocagem, liquefação, regaseificação e comercialização de Gás Natural ${ }^{51}$. Dessa forma, o legislador buscou tanto alterar quanto complementar a Lei do Petróleo no que tange as atividades do setor de Gás Natural.

A união das referidas atividades forma a chamada cadeia produtiva do Gás Natural, composta por diversos segmentos tecnologicamente separáveis, mas com elevado grau de interdependência ${ }^{52}$. Atualmente é comum dividir as atividades da cadeia do Gás Natural em três seguimentos: upstream (exploração e produção), midstream (tratamento, estocagem e transporte, tanto por dutos quanto por navios, no caso do GNL) e downstream (distribuição e comercialização). Segue abaixo figura ilustrando a referida organização:

\footnotetext{
${ }^{50}$ ROSADO, Marilda. Direito do petróleo. 3 ed. Rio de Janeiro: Renovar, 2014. p. 595.

$51<$ http://www.planalto.gov.br/ccivil_03/_Ato2007-2010/2009/Lei/L11909.htm>. Acesso em: 25 de out. de 2017

52 ALMEIDA, Edmar; FERRARO, Marcelo. Indústria do gás natural: fundamentos técnicos e econômicos. 1 ed. Rio de Janeiro: Synergia, 2013. p. 14.
} 
Figura 4: Cadeia de Valor do Gás Natural

Cadeia do Valor do Gás Natural

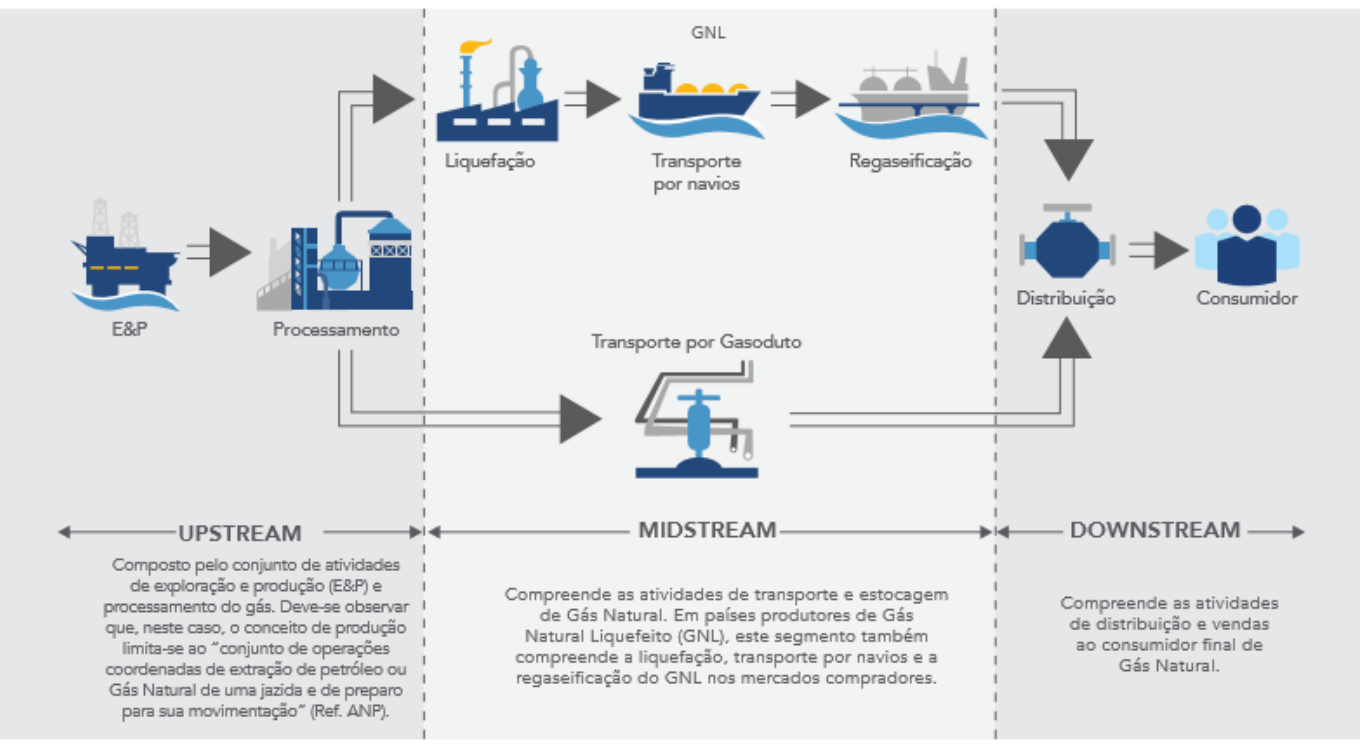

Fonte: GOMES, Ieda; HOLLANDA, Lavinia; MUÑOZ, Camilo; QUINTELLA, Carlos. Cadernos FGV Energia. Novembro 2014, Ano 1, ${ }^{\circ}$ 2, ISSN $2358-5277$.

Em consonância com o conceito de cadeia do Gás Natural, a Lei do Gás definiu "Indústria do Gás Natural" como o conjunto de atividades econômicas relacionadas com exploração, desenvolvimento, produção, importação, exportação, processamento, tratamento, transporte, carregamento, estocagem, acondicionamento, liquefação, regaseificação, distribuição e comercialização de Gás Natural.

De acordo com a Lei do Gás, entende-se por (i) tratamento ou processamento de Gás Natural, o conjunto de operações destinadas a permitir o seu transporte, distribuição e utilização, (ii) transporte de Gás Natural, a movimentação de gás natural em gasodutos de transporte, abrangendo a construção, a expansão e a operação das instalações, (iii) estocagem de Gás Natural, o armazenamento em reservatórios naturais ou artificiais, (iv) acondicionamento de Gás Natural, o confinamento de gás natural na forma gasosa, líquida ou sólida para o seu transporte ou consumo, e (v) comercialização de Gás Natural, a atividade de compra e 
venda de gás natural, realizada por meio da celebração de contratos negociados entre as partes e registrados na ANP.

As demais atividades citadas anteriormente que compõe a cadeia do Gás Natural e não se encontram diretamente definidas na Lei do Gás, possuem seus significados definidos na Lei do Petróleo, como no caso da atividade de distribuição ${ }^{53}$, ou foram definidas de forma indireta, como no caso das atividades de liquefação e regaseificação, através das definições de "Unidade de Liquefação", que corresponde à instalação na qual o Gás Natural é liquefeito, de modo a facilitar a sua estocagem e transporte, e "Unidade de Regaseificação", que corresponde à instalação na qual o GNL é regaseificado mediante a imposição de calor para ser introduzido na malha dutoviária.

Podem ser destacados como os principais pontos tratados na Lei do Gás ${ }^{54}$ :

(a) Transferência de competências da ANP para a União através do MME, conforme previsto nos artigos primeiro ${ }^{55}$ e quarto ${ }^{56}$ da lei, esvaziando as competências da agência reguladora;

(b) Introdução do regime de concessão precedida de licitação para a atividade de transporte de Gás Natural ${ }^{57}$ nos gasodutos de transporte considerados de interesse geral, mediante celebração de contratos de

\footnotetext{
${ }^{53}$ De acordo com a Lei do Petróleo, entende-se por "Distribuição de Gás Canalizado: serviços locais de comercialização de gás canalizado, junto aos usuários finais, explorados com exclusividade pelos Estados, diretamente ou mediante concessão, nos termos do $\S 2^{\circ}$ do art. 25 da Constituição Federal"

${ }^{54}$ NETO, Artur Watt. Petróleo, gás natural e biocombustíveis: doutrina, jurisprudência e legislação. 1 ed. São Paulo: Saraiva, 2014. p. 102.

${ }^{55}$ Nos termos do parágrafo primeiro do artigo primeiro da Lei do Gás: "As atividades econômicas de que trata este artigo serão reguladas e fiscalizadas pela União, na qualidade de poder concedente, e poderão ser exercidas por empresa ou consórcio de empresas constituídos sob as leis brasileiras, com sede e administração no País."

${ }^{56}$ Artigo quarto da Lei do Gás: "Caberá ao Ministério de Minas e Energia: I - propor, por iniciativa própria ou por provocação de terceiros, os gasodutos de transporte que deverão ser construídos ou ampliados; II - estabelecer as diretrizes para o processo de contratação de capacidade de transporte; III - definir o regime de concessão ou autorização, observado o disposto no $§ 1$ o do art. 3o desta Lei.”.

${ }^{57}$ Artigo terceiro: "A atividade de transporte de gás natural será exercida por sociedade ou consórcio cuja constituição seja regida pelas leis brasileiras, com sede e administração no País, por conta e risco do empreendedor, mediante os regimes de: I - concessão, precedida de licitação; ou II - autorização. $\S 1^{\circ} \mathrm{O}$ regime de autorização de que trata o inciso II do caput deste artigo aplicar-seá aos gasodutos de transporte que envolvam acordos internacionais, enquanto o regime de concessão aplicar-se-á a todos os gasodutos de transporte considerados de interesse geral(...)".
} 
concessão com prazo de 30 anos prorrogáveis pelo mesmo período. O regime de autorização (ato discricionário e precário que não requer licitação prévia) previsto na Lei do Petróleo foi mantido para os gasodutos que envolvam acordos internacionais bem como para aqueles autorizados antes da edição da Lei do Gás. Note-se que o prazo de 30 anos também é aplicável às autorizações que já vigoravam antes da Lei do Gás e que por essa foram ratificadas, contando o prazo a partir da publicação da referida lei;

(c) Instituição do procedimento de chamada pública prévia à licitação promovido pela ANP, com o intuito de verificar a demanda de gasodutos a serem concedidos ${ }^{58}$. No que tange as tarifas, determinou-se competência da ANP para determina-las e, nos casos envolvendo regime de autorização, estabeleceu-se competência do transportador para propor as tarifas à ANP mediante critérios previamente estabelecidos pela agência reguladora;

(d) Estabeleceu-se como principal critério de licitação a menor receita anual ofertada ${ }^{59}$;

(e) Estabeleceu-se que os bens destinados à exploração da atividade de transportes, o que inclui os gasodutos e equipamentos acessórios, serão incorporados ao patrimônio da União ao final da concessão ${ }^{60}$ e poderão ser licitados em conjunto com a concessão seguinte ${ }^{61}$;

\footnotetext{
${ }^{58} \mathrm{Na}$ forma dos artigos quinto "A outorga de autorização ou a licitação para a concessão da atividade de transporte que contemple a construção ou a ampliação de gasodutos será precedida de chamada pública para contratação de capacidade, com o objetivo de identificar os potenciais carregadores e dimensionar a demanda efetiva. (...)" e sexto "A ANP, conforme diretrizes do Ministério de Minas e Energia, promoverá, direta ou indiretamente, o processo de chamada pública de que trata o art. 5o desta Lei.".

${ }^{59}$ Artigo 13: "No processo de licitação, o critério para a seleção da proposta vencedora será o de menor receita anual, na forma da regulamentação e do edital.".

${ }^{60}$ Artigo 14: "Extinta a concessão, os bens destinados à exploração da atividade de transporte e considerados vinculados serão incorporados ao patrimônio da União, mediante declaração de utilidade pública e justa e prévia indenização em dinheiro, ficando sob a administração do poder concedente, nos termos da específica regulamentação a ser editada.".

${ }^{61}$ Artigo 15: "Os bens incorporados ao patrimônio da União na forma do art. 14 desta Lei poderão compor o conjunto de bens e instalações a serem licitados em conjunto com a nova concessão para a exploração da atividade de transporte.”.
} 
(f) Garantiu-se o livre acesso ${ }^{62}$, também conhecido como open access, que consiste no acesso de terceiros às instalações existentes, respeitado o período de exclusividade ${ }^{63}$ do carregador ${ }^{64}$, bem como a cessão de capacidade $^{65}$, que seria a transferência, no todo ou em parte, da utilização da capacidade contratada sob modalidade firme, descrita a seguir.

Para garantir tais práticas, a Lei do Gás estabeleceu as seguintes modalidades de contratação de serviço de transporte: (i) firme, no qual se permite acesso de terceiros na chamada capacidade disponível, que seria justamente a capacidade de transporte do gasoduto ainda não contratada; (ii) interruptível, no qual se permite o acesso de terceiros na chamada capacidade ociosa, que seria a capacidade contratada mas que não está em utilização no momento; e (iii) extraordinário, no qual se permite o acesso de terceiros na capacidade disponível enquanto não houver contratação dessa capacidade na modalidade firme. Conforme atualmente previsto na Resolução ANP $\mathrm{n}^{\circ}$ 11, de 18 de março de 2016, o transportador deve apresentar as formas em que se dará esse acesso mediante apresentação de documento intitulado "Termos de Acesso", que consiste nos termos e condições, tarifários e não-tarifários, para acesso de terceiros as suas instalações;

(g) A atividade de estocagem de Gás Natural passou a ser tratada também pelo regime de concessão ${ }^{66}$;

(h) Criou-se um regime diferenciado para os terminais de liquefação e regaseificação de GNL, não mais sujeitos a obrigações de livre acesso ${ }^{67}$;

\footnotetext{
${ }^{62}$ Artigo 32: "Fica assegurado o acesso de terceiros aos gasodutos de transporte, nos termos da lei e de sua regulamentação, observado o disposto no $\S 2^{\circ}$ do art. $3^{\circ}$ e no $\S 3$ - do art. 30 desta Lei.".

${ }^{63}$ Período definido pelo MME, após ouvida a ANP, para exploração da capacidade contratada dos novos gasodutos de transporte de maneira exclusiva pelo carregador.

${ }^{64}$ Conforme definido pela Lei do Gás, considera-se carregador o "agente que utilize ou pretenda utilizar o serviço de movimentação de gás natural em gasoduto de transporte, mediante autorização ANP".

${ }^{65}$ Artigo 35: "Fica autorizada a cessão de capacidade, assim entendida como a transferência, no todo ou em parte, do direito de utilização da capacidade de transporte contratada sob a modalidade firme.".

${ }^{66}$ Artigo 37: "A atividade de estocagem de gás natural será exercida por empresa ou consórcio de empresas, desde que constituídos sob as leis brasileiras, com sede e administração no País, por conta e risco do empreendedor, mediante concessão, precedida de licitação, ou autorização.”.
} 
(i) Foram criadas as figuras do consumidor livre, autoprodutor e autoimportador de Gás Natural, que são os consumidores de grande porte com capacidade para providenciar seu próprio fornecimento de Gás Natural, mediante compra de grandes fornecedores de maneira direta, produzindo seu próprio Gás Natural ou importando-o em nome próprio ${ }^{68}$. Nos casos em que a necessidade de movimentação de Gás Natural não possa ser atendida pela distribuidora estadual, a Lei prevê também a possibilidade desses agentes construírem e implementarem, diretamente, instalações de dutos para uso específico através da celebração de contratos atribuindo à distribuidora estadual a operação e manutenção de tais instalações ${ }^{69}$. Pela prestação de tais serviços a distribuidora estadual recebe tarifa estipulada pelo órgão regulador estadual, que estabelecerá a tarifa com base nos princípios administrativos da razoabilidade, transparência e publicidade;

(j) Obrigação de registro de todos os contratos de comercialização de Gás Natural perante a $\mathrm{ANP}^{70}$;

(k) Foi prevista a possibilidade de se estipular procedimento arbitral tanto nos contratos de concessão quanto nos contratos de transporte e de comercialização de Gás Natural; e

(1) Criação do plano nacional de contingência para eventual caso de ruptura do sistema que gerasse necessidade de racionamento de Gás Natural ${ }^{71}$, mediante proposição pelo CNPE e decreto do Presidente da República.

\footnotetext{
67 Artigo 45: "Os gasodutos de escoamento da produção, as instalações de tratamento ou processamento de gás natural, assim como os terminais de liquefação e regaseificação, não estão obrigados a permitir o acesso de terceiros.”.

68 Artigo 46: "O consumidor livre, o autoprodutor ou o auto-importador cujas necessidades de movimentação de gás natural não possam ser atendidas pela distribuidora estadual poderão construir e implantar, diretamente, instalações e dutos para o seu uso específico, mediante celebração de contrato que atribua à distribuidora estadual a sua operação e manutenção, devendo as instalações e dutos ser incorporados ao patrimônio estadual mediante declaração de utilidade pública e justa e prévia indenização, quando de sua total utilização.”.

${ }^{69}$ ROSADO, Marilda. Direito do petróleo. 3 ed. Rio de Janeiro: Renovar, 2014. p. 595.

${ }^{70}$ Artigo 47: "Ressalvado o disposto no § 2o do art. 25 da Constituição Federal, a comercialização de gás natural dar-se-á mediante a celebração de contratos registrados na ANP.”.

${ }^{71}$ Artigo 50: "Em situações caracterizadas como de contingência no suprimento de gás natural, mediante proposição do Conselho Nacional de Política Energética - CNPE e decreto do Presidente
} 
Mediante análise dos principais pontos listados, verifica-se que o legislador teve maior foco nas atividades de midstream ao aprovar a Lei do Gás, uma vez que as atividades de produção e distribuição continuam reguladas pela Lei do Petróleo e pelo artigo 25 da Constituição Federal, respectivamente ${ }^{72}$.

Por sua vez, o Decreto 7.382, de 2 de dezembro de 2010, que regula a Lei do Gás, além de regular o acesso e uso das instalações de transporte de Gás Natural, e a definição de regras para a redução/extinção do período de exclusividade dos carregadores, previu a troca operacional, também conhecida como swap e posteriormente tratada pela Resolução ANP ${ }^{\circ}$ 11/2016, que basicamente consiste no acesso de terceiros aos gasodutos de transporte mediante serviço de transporte no qual fluxos físico e contratual diferem, no todo ou em parte, contribuindo para a operação eficiente da instalação de transporte ${ }^{73}$.

As atividades de exploração, desenvolvimento e produção de Gás Natural permaneceram reguladas pelo artigo 23 da Lei do Petróleo ${ }^{74}$, através do regime de concessão precedida de licitação promovida pela ANP.

Além disso, a Lei do Gás estabeleceu que as atividades de importação e exportação de Gás Natural dependerão de autorização do MME, sendo exercidas com observância às diretrizes do CNPE, conforme previsto no artigo 36 da lei ${ }^{75}$.

da República, as obrigações de fornecimento de gás, em atividades da esfera de competência da União, e de prestação de serviço de transporte, objeto de contratos celebrados entre as partes, poderão ser suspensas, em conformidade com diretrizes e políticas contidas em Plano de Contingência, nos termos da regulamentação do Poder Executivo.”.

${ }^{72}$ ROSADO, Marilda. Direito do petróleo. 3 ed. Rio de Janeiro: Renovar, 2014. p. 596.

${ }^{73}$ ROSADO, Marilda. Direito do petróleo. 3 ed. Rio de Janeiro: Renovar, 2014. p. 596.

${ }^{74}$ Artigo 23: "As atividades de exploração, desenvolvimento e produção de petróleo e de gás natural serão exercidas mediante contratos de concessão, precedidos de licitação, na forma estabelecida nesta Lei, ou sob o regime de partilha de produção nas áreas do pré-sal e nas áreas estratégicas, conforme legislação específica.".

${ }^{75}$ Artigo 36: "Qualquer empresa ou consórcio de empresas, desde que constituídos sob as leis brasileiras, com sede e administração no País, poderão receber autorização do Ministério de Minas e Energia para exercer as atividades de importação e exportação de gás natural. Parágrafo único. $\mathrm{O}$ exercício das atividades de importação e exportação de gás natural observará as diretrizes estabelecidas pelo CNPE, em particular as relacionadas com o cumprimento do disposto no art. 40 da Lei no 8.176, de 8 de fevereiro de 1991.”. 
Cumpre destacar também, que os regimes de concessão e autorização previstos na Lei do Gás não se confundem com os regimes de concessão, permissão e autorização para serviços públicos previstos na Lei ${ }^{\circ} 8.987$, de 13 de fevereiro de 1995, também conhecida como Lei de Concessões, uma vez que a Lei do Gás trata das atividades econômicas previstas como monopólio da União no artigo 177 da Constituição Federal e a Lei de Concessões trata da prestação de serviços públicos, previstos no artigo 175 da Constituição Federal.

A Lei do Gás previu também a possibilidade do MME utilizar o instrumento de Parceria Público Privada - "PPP" para construção de gasoduto de transporte de Gás Natural que seja considerado de relevante interesse público ${ }^{76}$.

Segue abaixo um quadro resumo das atividades/regimes previstos na Lei do Petróleo e Lei do Gás, para facilitar a visualização:

Figura 5: Tabela Comparativa da Lei do Petróleo e Lei do Gás

\begin{tabular}{|c|c|c|}
\hline Assunto & Lei do Petróleo & Lei do Gás \\
\hline $\begin{array}{l}\text { Exploração, } \\
\text { desenvolvimento } \\
\text { produção }\end{array}$ & $\begin{array}{l}\text { Concessão Precedida } \\
\text { de Licitação }\end{array}$ & Não trata do assunto \\
\hline $\begin{array}{l}\text { Distribuição } \\
\text { comercialização }\end{array}$ & $\begin{array}{l}\text { Exploração pelos } \\
\text { Estados, diretamente } \\
\text { ou mediante concessão }\end{array}$ & $\begin{array}{l}\text { Registro dos contratos } \\
\text { na ANP }\end{array}$ \\
\hline $\begin{array}{l}\text { Transporte de Gás } \\
\text { Natural }\end{array}$ & $\begin{array}{l}\text { Autorização da ANP } \\
\text { sem previsão de prazo }\end{array}$ & $\begin{array}{l}\text { Autorização em casos } \\
\text { específicos } \\
\text { concessão precedida de }\end{array}$ \\
\hline
\end{tabular}

\footnotetext{
${ }^{76}$ Parágrafo segundo do artigo quarto da Lei do Gás estabelece que o MME “poderá determinar a utilização do instrumento de Parceria Público Privada, de que trata a Lei no 11.079 , de 30 de dezembro de 2004, bem como a utilização de recursos provenientes da Contribuição de Intervenção no Domínio Econômico - CIDE e da Conta de Desenvolvimento Energético, na forma do disposto no art. 13 da Lei no 10.438, de 26 de abril de 2002, para viabilizar a construção de gasoduto de transporte proposto por sua própria iniciativa e considerado de relevante interesse público."
} 


\begin{tabular}{|c|c|c|}
\hline & & $\begin{array}{l}\text { licitação com prazo de } \\
30 \text { anos prorrogável } \\
\text { pelo mesmo período }\end{array}$ \\
\hline $\begin{array}{l}\text { Contratos de transporte } \\
\text { de Gás Natural }\end{array}$ & $\begin{array}{l}\text { ANP recebia os } \\
\text { contratos após terem } \\
\text { sido celebrados }\end{array}$ & $\begin{array}{l}\text { Aprovação prévia da } \\
\text { ANP }\end{array}$ \\
\hline Novos gasodutos & $\begin{array}{l}\text { Proposição dos agentes } \\
\text { do setor de Gás Natural }\end{array}$ & Proposição pelo MME \\
\hline $\begin{array}{l}\text { Importação } \\
\text { exportação }\end{array}$ & Autorização da ANP & Autorização do MME \\
\hline $\begin{array}{l}\text { Refinação, } \\
\text { processamento, } \\
\text { liquefação } \\
\text { regaseificação }\end{array}$ & Autorização da ANP & Autorização da ANP \\
\hline Plano de contingência & Não trata do assunto & $\begin{array}{l}\text { Proposto pelo CNPE e } \\
\text { decretado } \\
\text { Presidente } \\
\text { República }\end{array}$ \\
\hline $\begin{array}{l}\text { Introdução de novos } \\
\text { agentes no setor }\end{array}$ & Não trata do assunto & $\begin{array}{ll}\text { Criação } & \text { do } \\
\text { autoprodutor, } & \\
\text { autoimportador } & \text { e } \\
\text { consumidor livre } & \end{array}$ \\
\hline
\end{tabular}

Fonte: Elaboração própria 


\section{CAPÍTULO 3 - GÁS PARA CRESCER, PRINCIPAIS CRÍTICAS AO SETOR DO GÁS NATURAL E O NOVO MARCO REGULATÓRIO PROPOSTO}

\subsection{Introdução}

Passados oito anos desde a publicação da Lei do Gás, nota-se que, apesar dos importantes avanços legislativos e regulatórios, não é possível verificar um aumento significativo na participação de novos agentes no setor de Gás Natural.

Conforme mencionado anteriormente, a Petrobras ainda figura como agente dominante do setor de Gás Natural no Brasil, sendo responsável pela produção de $81 \%$ do gás nacional, $95 \%$ da oferta total de Gás Natural ao mercado, bem como proprietária da maior parte dos ativos de escoamento, transporte e tratamento, além de possuir participação em 20 das 27 distribuidoras de gás do país e ser a maior consumidora de Gás Natural do país, consumindo $40 \%$ da oferta total.

Neste capítulo trataremos de forma concomitante as principais críticas ao setor de Gás Natural no Brasil e a iniciativa do MME para ampliação da discussão no setor, objetivando a proposição de medidas concretas para o aprimoramento do arcabouço normativo.

Por fim, analisaremos o recém-proposto novo marco regulatório do Gás Natural.

\subsection{Gás Para Crescer e as Principais Críticas ao Setor}

Em sintonia com o conjunto de fatores anteriormente detalhados que compõem o atual cenário do setor de Gás Natural no Brasil, tais como a elevada concentração da oferta e demanda no setor, os atuais desinvestimentos feitos pela Petrobras, a revolução mundial experimentada pela indústria do Gás Natural, o aumento na exploração do gás do Pré-sal 
na próxima década e o aumento da necessidade de termelétricas na matriz energética brasileira, no dia 24 de junho de 2016 o MME lançou a iniciativa intitulada "Gás para Crescer", conforme anunciado pelo Ministro Minas e Energia Fernando Coelho Filho: "O Ministério de Minas e Energia vai estudar e elaborar propostas com o objetivo de manter o funcionamento adequado do setor de gás, diante de um cenário de redução da participação da Petrobras (...) essa possibilidade representa oportunidade de diversificação dos agentes do setor, com o aumento da competição. Isso merece atenção do poder concedente e dos órgãos responsáveis pelo planejamento e regulação energética, para mitigar riscos de ordem regulatória sem representar entraves desnecessários à entrada de novos agentes, atraindo investimentos importantes para o país. "77.

De acordo com o documento "Diretrizes Estratégicas para o desenho de novo mercado de gás natural no Brasil" compreendido no âmbito da iniciativa e disponibilizado no sítio do $\mathrm{MME}^{78}$, o Gás para Crescer apresenta como visão de futuro um mercado de Gás Natural com diversidade de agentes, liquidez, competitividade, acesso à informação e boas práticas da indústria. Para tal, a referida iniciativa foi criada com objetivo de propor medidas concretas visando o aprimoramento do arcabouço normativo do setor de Gás Natural por meio da promoção de discussões pelo MME, em conjunto com a EPE e a ANP, com os diversos agentes da indústria do Gás Natural no Brasil.

Dentre as principais premissas do Gás para Crescer, destacam-se: (i) a adoção de boas práticas internacionais; (ii) a atração de investimentos; (iii) o aumento da competição; (iv) diversidade de agentes; (v) maior

\footnotetext{
${ }^{77}<$ http://www.mme.gov.br/web/guest/pagina-inicial/outras-noticas/-

/asset_publisher/32hLrOzMKwWb/content/mme-abre-consulta-sobre-diretrizes-propostas-pelogas-para-crescer>.

Acesso em: 27 de out. de 2017

$78<$ http://www.mme.gov.br/web/guest/consultas-

publicas?p_p_id=consultapublicaexterna_WAR_consultapublicaportlet\&p_p_lifecycle=0\&p_p_st ate=normal\&p_p_mode=view\&p_p_col_id=column-

1\&p_p_col_count $=1$ \&_consultapublicaexterna_WAR_consultapublicaportlet_consultaId=20\&_co nsultapublicaexterna_WAR_consultapublicaportlet_mvcPath $=\% 2 \mathrm{Fhtml} \% 2 \mathrm{Fpublico} \% 2 \mathrm{FdadosCon}$ sultaPublica.jsp>.

Acesso em: 27 de out. de 2017
} 
dinamismo e acesso à informação; (vi) a participação dos agentes do setor; e (vii) o respeito aos contratos.

Para alcançar os referidos objetivos à luz de tais premissas, o Gás para Crescer foi composto por um conjunto de frentes de trabalho coordenadas pelo MME, EPE e ANP, que sintetizam os conjuntos temáticos objeto de discussão com os agentes do setor de Gás Natural. Segue abaixo uma síntese dos cinco principais pontos de discussão no âmbito da iniciativa, refletindo as principais críticas ao setor bem como as soluções $\operatorname{propostas}^{79}$ :

(a) Comercialização de gás natural: atualmente a demanda no mercado de Gás Natural brasileiro é caracterizada pelo grande poder de decisão na aquisição do gás concentrado em cinco agentes proprietários das 27 distribuidoras de gás natural, com participação da Petrobras em 20 dessas 27 distribuidoras. No que tange a oferta, a Petrobras é praticamente a única fornecedora de Gás Natural ao mercado, responsável por 95\% da oferta total. Tal fenômeno no qual uma empresa atua em mais de uma estágio da cadeia produtiva é também conhecido como a "Verticalização" do setor de Gás Natural.

No âmbito da iniciativa Gás para Crescer, propôs-se a adoção de medidas que possibilitem a desverticalização do setor por meio do estímulo à competição na oferta de Gás Natural e limitação da concentração de mercado / self-dealing praticado pela Petrobras ${ }^{80}$ (claro conflito de interesses da estatal, que fere frontalmente os princípios da concorrência e livre iniciativa previstos na Constituição Federal, prejudicando o consumidor final), proporcionando a existência de múltiplos comercializadores e garantindo que os agentes de mercado efetivamente negociem contratos bilateralmente, favorecendo o acesso não discriminatório desses agentes à infraestrutura da cadeia do Gás Natural,

\footnotetext{
${ }^{79}<$ http://www.mme.gov.br/documents/10584/4006960/0+G\%C3\%A1s+para+Crescer_Relat\%C3 \%B3rio+T\%C3\%A9cnico.pdf/92738252-2868-4394-a9fc-b6f4fd9e6bc7>. Acesso em: 27 de out. de 2017

${ }^{80}$ Quando a Petrobras negocia de forma direta, ou através de empresas que detém participação, com si própria nas diferentes atividades da cadeia do gás
} 
bem como a transparência e a alocação eficiente de capacidade de transporte.

Além disso, entende-se que deve ser estimulada a criação de mercados de curto prazo e secundário, que seriam justamente o oposto ao controle de um agente dominante por meio de contratos de longo prazo que ocorre atualmente no Brasil, nos quais ocorreria a venda de Gás Natural de produtores privados e potenciais comercializadores diretamente às distribuidoras estaduais e consumidores livres, via contratação de capacidade em gasodutos de transporte, servindo como mecanismos de mitigação do risco da entrega física do Gás Natural, ao qual possam recorrer tanto produtores quanto consumidores de Gás Natural para assegurar o cumprimento dos contratos.

(b) Compartilhamento de infraestruturas: A Petrobras responde por $81 \%$ da produção nacional de Gás Natural, e adquire diretamente de agentes privados na chamada "boca de poço" 81 o restante do gás produzido no Brasil, tornando-se responsável por $99,8 \%$ do Gás Natural que entra nos gasodutos de transporte. Isso ocorre porque as atividades de processamento e de regaseificação (no caso do GNL) de Gás Natural são indispensáveis à injeção do Gás Natural explorado no sistema de transporte, e a infraestrutura necessária para realização de tais atividades não é considerada de acesso obrigatório pela Lei do Gás, conforme anteriormente tratado, que prevê a negociação entre as partes, minando a competitividade do setor.

Conforme discutido no Gás para Crescer, foram propostas medidas que possibilitem a regulamentação do acesso de terceiros aos gasodutos de escoamento da produção, Unidades de Processamento de Gás Natural UPGNs e terminais de regaseificação, por meio da aplicação da chamada essential facilities doctrine ${ }^{82}$, impondo aos titulares de instalações

\footnotetext{
${ }^{81}$ Quando se adquire no Gás Natural nas proximidades da sua exploração, sem que passe pelas atividades de processamento, transporte, etc.

${ }^{82}$ Doutrina implantada nos Estados Unidos cujo princípio é de que a recusa de acesso pode constituir um abuso da posição dominante por parte do incumbente.
} 
essenciais o dever de negociar com seus competidores o acesso. Para tal, é necessário que o novo arcabouço regulatório preveja as condições de acesso a infraestrutura.

Cumpre destacar o desafio de disciplinar tal acesso de forma a preservar os direitos existentes dos proprietários e carregadores iniciais, as boas práticas da indústria (transparência e publicidade das principais informações requeridas para o acesso de terceiros, padronização dos contratos, princípios de cálculo de tarifa que fundamentem a negociação entre as partes) bem como observar as condições técnicas de operação de tais instalações (existência de capacidade disponível, especificações técnicas condicionantes financeiros, etc.), em benefício do estimulo à concorrência.

(c) Tarifação por entradas e saídas: no Brasil são atualmente utilizadas as tarifações por distância e postal, para remuneração da atividade de transporte de Gás Natural. A tarifação por distância tem como principal atrativo a refletividade de custos, o que a torna preferível em gasodutos longos e unidirecionais. Por outro lado, tal tarifação tem o inconveniente de ser calculada caso-a-caso, reduzindo a transparência do custo do transporte e dificultando o cálculo econômico por parte dos agentes do mercado. Além disso, na medida em que a rede de transporte torna-se mais complexa e interconectada, os fluxos físicos de gás na malha ocorrem em diferentes direções, fazendo com que a tarifação por distância não reflita os reais custos do serviço de transporte.

Por sua vez a tarifação postal se caracteriza pela cobrança uniforme de todos os usuários, independentemente da distância ou localização deles na rede. Por não refletir exatamente o custo de transporte para o local de seu uso, esse método tem como característica subsidiar a movimentação do gás natural para os locais mais distantes das fontes de oferta, privilegiando a universalização do serviço em detrimento da emissão de sinais locacionais eficientes. 
No âmbito do Gás para Crescer, foi proposta a metodologia de "tarifação por entradas e saídas" amplamente utilizada no âmbito internacional, na qual as tarifas são específicas para cada ponto de recebimento e para cada ponto de entrega ${ }^{83}$, sem vinculação entre as tarifas cobradas e o caminho que o gás deve percorrer entre os pontos de entrada e saída utilizados, refletindo de maneira real os custos de transporte, beneficiando a concorrência no mercado e atraindo novos investimentos.

(d) Harmonização entre as regulações Estaduais e Federal: Conforme mencionado anteriormente, o parágrafo segundo do artigo 25 da Constituição Federal atribui aos Estados competência para explorar o serviço local de gás canalizado. Verifica-se no Brasil a necessidade de aperfeiçoamento e padronização dos marcos e das estruturas regulatórias dos Estados, uma vez que o atual cenário é de desalinhamento entre tais regulações com os Estados apresentando diferentes estruturas e normas para regular o setor, gerando incertezas jurídicas e o aumento dos custos de transação. Como exemplo do referido desalinhamento, algumas das Unidades da Federação não possuem agência reguladora bem como não há similaridade e padronização no tratamento dado ao autoprodutor, autoimportador e consumidor livre criados pela Lei do Gás.

Desse modo, propôs-se no Gás para Crescer a adoção de melhores práticas regulatórias, tais como a transparência, autonomia e previsibilidade, na busca por um alinhamento entre as regulações Estaduais e Federal.

(e) Gestão independente e integrada do sistema de transporte: Atualmente a atividade de transporte de gás natural é regulada considerando a movimentação do Gás Natural por meio de gasodutos de transporte singularizados. Faz-se necessária uma mudança de paradigma através de nova modelagem e regulação que tratem a malha de gasodutos de transporte como um sistema integrado.

\footnotetext{
${ }^{83}$ Entende-se por ponto de recebimento o local aonde o transportador recebe o Gás Natural do carregador para injetá-lo no gasoduto de transporte. Por sua vez, entende-se por ponto de entrega o local aonde o transportador devolve o gás transportador ao carregador.
} 
De acordo com as discussões realizadas no âmbito do Gás para Crescer, tal mudança de paradigma demanda a implantação de uma gestão independente integrada do sistema de transporte de Gás Natural, que atue de forma semelhante ao Operador Nacional do Sistema Elétrico - ONS no setor elétrico ${ }^{84}$, propiciando os incentivos adequados à promoção do acesso não discriminatório, à eficiência na operação do sistema de transporte e à transparência das informações de capacidade e utilização do sistema.

$\mathrm{O}$ gestor independente consistiria numa empresa privada independente, regulada e fiscalizada pela ANP e remunerada pelos usuários do sistema de transporte de gás por meio de tarifa regulada pela ANP com base em indicadores de desempenho. Dentre os principais benefícios proporcionados por uma gestão independente, temos a redução dos custos de transação bem como a facilitação no cálculo tarifário, considerando a centralização de informações em um único agente, além de pressupor-se uma adequada alocação das capacidades de transporte dos gasodutos de transporte e uma otimização de fluxos.

Contudo, a implantação de uma gestão independente e integrada esbarra na necessidade de se preservar a segurança jurídica por meio do respeito aos contratos existentes, uma das diretrizes do Gás para Crescer mencionadas anteriormente, protegidos também pela Constituição Federal que estabelece o respeito ao ato jurídico perfeito e ao direito adquirido. Além disso, propôs-se a implantação da reserva de capacidade por entrada e saída, que dialoga com a tarifação por entrada e saída, permitindo a contratação de maneira separada de capacidades de entrada ou de saída e a comercialização de gás de forma independente de sua localização na rede, o que aumentaria o número de agentes aptos a negociar entre si e favoreceria a formação de mercados secundários e a competição na oferta.

Vale destacar também a sugestão, no âmbito do Gás para Crescer, de mudanças nos modelos de outorga para exploração das atividades de

\footnotetext{
${ }^{84}$ Operador Nacional do Sistema Elétrico (ONS) é o órgão responsável pela coordenação e controle da operação das instalações de geração e transmissão de energia elétrica no Sistema Interligado Nacional (SIN), atuando sob a fiscalização e regulação da ANEEL.
} 
transporte e estocagem de Gás Natural, especialmente quanto aos critérios para adoção de outorga de autorização ou de concessão e à simplificação do processo, conforme posteriormente refletido na proposta de novo marco regulatório analisada abaixo.

\subsection{Novo Marco Regulatório do Gás Natural}

Em seguimento às discussões travadas no âmbito da iniciativa Gás para Crescer, no dia 16 de outubro de 2017 foi apresentado em reunião da Comissão de Minas e Energia - CME da Câmara dos Deputados ${ }^{85} \mathrm{o}$ Substitutivo ao Projeto de Lei 6.407/2013, que dispõe sobre medidas para fomentar a indústria do Gás Natural. Tal substitutivo tem como objetivo estabelecer o novo marco regulatório para o setor de Gás Natural, regulando as atividades de importação e exportação, transporte, escoamento, tratamento, processamento, estocagem (subterrânea inclusive), acondicionamento, liquefação, regaseificação e comercialização de Gás Natural, por meio da incorporação das propostas que surgiram no Gás para Crescer, bem como propondo a revogação da Lei do Gás.

Em linhas gerais, o substitutivo propõe um grande deslocamento de competências, retomando o protagonismo da ANP no setor, bem como a retomada do regime de autorização, além de refletir conceitos propostos no Gás para Crescer, como por exemplo o novo tratamento a ser conferido à malha de transporte de Gás Natural, que deverá ser pensada como um sistema com gestão independente, o acesso obrigatório à infraestrutura de processamento, escoamento, regaseificação, a contratação de capacidade/tarifação por entrada e saída, a criação de mercados organizados para a comercialização de Gás Natural e a regulação da atividade de estocagem subterrânea.

\footnotetext{
${ }^{85}<$ http://terciotti.com.br/news/substitutivo-do-pl-do-gas-e-finalizado-e-ja-pode-recebercontribuicoes/>. Acesso em: 20 de out. 2017
} 
Entretanto, apesar de se basear no Gás para Crescer e buscar atender a questões levantadas pelos agentes do setor, o substitutivo carece de clareza com relação à nova dinâmica proposta para algumas das atividades da cadeia do Gás Natural, deixando muitos pontos importantes em aberto para posterior regulação da ANP (tratamento semelhante ao conferido pela Lei do Petróleo), além de resvalar em complicações do ponto de vista jurídico/constitucional no que tange a competência Estadual para exploração dos serviços locais de gás canalizado, prevista na Constituição Federal, a reclassificação de gasodutos e a falta de respeito aos contratos de transporte de gás em vigor, conforme detalhado a seguir.

Seguem abaixo os principais pontos tratados no novo marco regulatório proposto para o setor de Gás Natural ${ }^{86}$ :

(a) Transporte de Gás Natural: De acordo com o substitutivo, a atividade de transporte de Gás Natural voltaria a ser exercida em regime de autorização precedida de chamada pública a ser conduzida e concedida pela ANP, e não mais pelo regime de concessão previsto na Lei do Gás, atendendo à demanda dos agentes do setor no âmbito do Gás para Crescer pela simplificação e celeridade dos processos. O processo de autorização deverá prever um período de contestação, no qual outros transportadores poderão manifestar interesse na implantação de gasoduto com a mesma finalidade, mitigando a discricionariedade do regime de autorização previsto anteriormente na Lei do Petróleo. Caso haja mais de um transportador interessado, a ANP deverá promover processo seletivo público para escolher o projeto mais vantajoso, considerando aspectos técnicos e econômicos.

Em uma espécie de "semi-livre iniciativa", a construção ou ampliação de gasodutos ou instalações de transporte poderá ser proposta pelos transportadores, através de planos coordenados de desenvolvimento do sistema de transporte, ou pela própria ANP via condução de processo

\footnotetext{
${ }^{86}<$ http://www.abegas.org.br/Site/wp-content/uploads/2017/10/Nova-lei-do-g\%C3\%A1snatural_16-Outubro-2017.pdf>. Acesso em: 30 de out. de 2017
} 
seletivo público para identificar a existência de transportadores interessados. Trata-se de modelo híbrido de iniciativa tanto dos agentes privados quanto do setor público, diferindo da iniciativa exclusiva do MME prevista na Lei do Gás.

Os transportadores deverão oferecer seus serviços por meio de plataforma eletrônica, adotar as “melhores práticas da indústria internacional do Gás Natural”, bem como operar de forma transparente e não discriminatória e eficiente, além de planejar e propor as ampliações e adequações necessárias ao atendimento da demanda por serviços de transporte. As atividades de estocagem subterrânea de gás e construção e operação de terminais de GNL também poderão ser exercidas pelos transportadores autorizados, que deverão operar os gasodutos de transporte com "independência e autonomia em relação aos agentes que exercem atividades potencialmente concorrenciais da cadeia de valor da indústria do Gás Natural”.

Além disso, objetivando a desverticalização do setor, vedou-se ao transportador possuir relação societária direta ou indireta, controlar, ser controlado, ou estabelecer coligação com empresas que atuem nas atividades de exploração, produção, importação, carregamento e comercialização de Gás Natural, reforçando a limitação prevista na Lei do Gás que proíbe que um mesmo agente seja carregador e transportador. Proibiu-se também aos agentes que atuem na exploração, produção, importação, carregamento, transporte e comercialização de Gás Natural o acesso a informações concorrencialmente sensíveis e o poder para eleger membro de conselho de administração ou diretoria das transportadoras e distribuidoras de Gás Natural.

Os agentes que tenham sido autorizados anteriormente para o exercício da atividade de transporte e que não preencham os "requisitos $e$ critérios de independência e autonomia" listados acima, deverão submeterse à certificação de independência expedida pela ANP, nos termos de sua 
regulação, com validade máxima até 2039. Após tal período de transição, todas as transportadoras deverão adequar-se a tais requisitos e critérios.

Conforme mencionado anteriormente, há grande polêmica no dispositivo do novo marco regulatório proposto que permite à ANP reclassificar os gasodutos de acordo com seus próprios critérios. Além de carecer de esclarecimentos com relação aos critérios que seriam adotados, tal previsão pode acarretar em prejuízos econômicos relevantes aos transportadores, a depender das reclassificações que forem feitas.

De acordo com o substitutivo, caberá também à ANP estipular uma receita máxima permitida de transporte, bem como os critérios de reajuste e revisão periódicos, nos termos da sua regulação. As tarifas de transporte de Gás Natural serão propostas pelo transportador e aprovadas pela ANP, segundo critérios por ela previamente estabelecidos, e deverão ser estruturadas com o objetivo de permitir que os transportadores obtenham receita suficiente para arcar com os custos e despesas vinculados à prestação de serviços e às obrigações tributárias, bem como para a obtenção da "remuneração justa e adequada ao investimento em bens e instalações vinculados à prestação dos serviços de transporte”.

De acordo com o novo marco regulatório proposto, a malha de gasodutos de transporte será tratada na forma de sistemas de transporte de Gás Natural, a serem regulados pela ANP. Caberá à agência estabelecer os critérios para classificação das instalações como integrantes dos sistemas de transporte, a formação de áreas de mercado de capacidade (delimitação do sistema de transporte onde o carregador poderá contratar os serviços de transporte oferecidos nas modalidades de capacidade por pontos de entrada e saída, que poderão ser contratadas de forma independente uma da outra, conforme discutido no Gás para Crescer), a formação de pontos virtuais de negociação de gás natural, e os critérios para a constituição e atuação dos gestores de mercado (agente regulado e fiscalizado pela ANP, constituído pelos transportadores que operem em uma determinada área de mercado de capacidade e responsável pela coordenação dos mesmos - na linha do 
operador independente proposto no Gás para Crescer), bem como as diretrizes para elaboração dos códigos comuns de redes (conjunto de regras com a finalidade de promover a operação não discriminatória pelos transportadores nos sistemas de transporte de Gás Natural, submetidos pelos gestores de área de mercado à aprovação da ANP).

Por fim, cumpre-se destacar o polêmico dispositivo previsto no substitutivo estabelecendo que os contrato de transporte de gás em vigor deverão ser "adequados, de modo a refletir as novas modalidades de contratação de serviço de transporte, preservando o equilíbrio econômicofinanceiro do transportador". Tal dispositivo contraria o respeito aos contratos, apontado no Gás para Crescer como uma de suas premissas, além de ferir princípios constitucionais, como o direito adquirido, a preservação do ato jurídico perfeito e a segurança jurídica.

(b) Importação e Exportação de Gás Natural: As atividades de importação e exportação de Gás Natural, anteriormente autorizadas pelo MME, passarão a ser autorizadas pela ANP e continuarão observando as diretrizes estabelecidas pelo CNPE.

(c) Estocagem Subterrânea de Gás Natural: A Lei do Gás trata das atividades de estocagem e acondicionamento de Gás Natural no mesmo capítulo. Por sua vez, o substitutivo apresentado propõe um capítulo exclusivo para a atividade de estocagem subterrânea de Gás Natural, que consistiria no armazenamento de Gás Natural em formações geológicas produtoras ou não de hidrocarbonetos. Tal atividade será objeto de autorização do Poder Concedente ou, por meio de delegação, da ANP, pelo prazo de 30 anos e podendo ser prorrogada por igual período. Além disso, o novo marco regulatório proposto assegura o acesso de terceiros às instalações de estocagem subterrânea de Gás Natural, nos termos da regulação da agência.

Manteve-se o regime de autorização, a ser concedida pela ANP, para a atividade de acondicionamento de Gás Natural. 
(d) Acesso à Infraestrutura: Conforme discutido anteriormente, o acesso de terceiros à infraestrutura por meio da aplicação da essential facilities doctrine figura como uma das principais questões tratadas no Gás para Crescer. De acordo com o novo marco regulatório proposto, as atividades de construção, ampliação de capacidade e operação de unidades de processamento, liquefação, regaseificação e gasodutos de escoamento serão reguladas pelo regime de autorização, a ser concedida pela ANP. O acesso às referidas instalações deverá ocorrer de forma não discriminatória por meio de negociações entre as partes, sendo que o proprietário da instalação terá preferência no uso da própria infraestrutura, forma da regulação da agência.

(e) Distribuição e Comercialização de Gás Natural: Como tratado anteriormente, o parágrafo segundo do artigo 25 da Constituição Federal estabelece competência estadual para explorar diretamente, ou mediante concessão, os serviços locais de gás canalizado. Entretanto, o novo marco regulatório proposto para o setor parece contraria tal previsão constitucional, estabelecendo que a comercialização de Gás Natural se dará apenas mediante celebração de contratos registrados na ANP, que deverá estabelecer inclusive o conteúdo mínimo de tais contratos, bem como a vedação às cláusulas que prejudiquem a concorrência.

Além disso, propôs-se que a atividade de comercialização deverá ser regulada pelo regime de autorização, a ser concedida pela agência as distribuidoras, consumidores livres, autoprodutores, autoimportadores e comercializadores.

Sem prejuízo da análise realizada, cumpre destacar que o Substitutivo ao Projeto de Lei 6.407/2013 foi recém apresentado à Comissão de Minas e Energia, de modo que ainda sofrerá, muito provavelmente, uma série de alterações durante sua tramitação no congresso. É necessário estarmos atentos às discussões, com o objetivo de construirmos o melhor marco regulatório possível para o setor de Gás Natural. 


\section{CONCLUSÃO}

Conforme tratado anteriormente, o desenvolvimento da indústria de Gás Natural no Brasil sempre esteve atrelado ao desempenho da Petrobras. Entretanto, a estatal atravessa um período de elevado nível de endividamento, e vem realizando importantes desinvestimentos no âmbito da indústria do Gás Natural objetivando reverter esse cenário.

Além disso, o mundo experimenta uma nova percepção do Gás Natural, que vem sendo visto como a fonte energética de transição para uma economia de baixo carbono. No caso do Brasil, há muita expectativa com relação ao possível desenvolvimento do gás do Pré-sal na próxima década, e as dificuldades hídricas experimentadas aumentam a necessidade de penetração do Gás Natural no setor elétrico, como no caso da utilização de termelétricas de gás.

Apesar das importantes conquistas trazidas pela Lei do Petróleo e pela Lei do Gás, tais leis apresentaram tratamento insuficiente à cadeia do Gás Natural, de modo que o monopólio de fato exercido pela Petrobras no setor de Gás Natural ainda se faz presente.

A partir das discussões travadas no âmbito da iniciativa Gás para Crescer e da apresentação do substitutivo ao projeto de Lei 6.407/2013, temos pela terceira vez a oportunidade de elaborarmos um marco regulatório que possibilite a consolidação de um mercado de Gás Natural com diversidade de agentes, liquidez, competitividade, acesso à informação e boas práticas, que contribua para o desenvolvimento do Brasil.

É necessário que estejamos atentos às discussões no âmbito do novo marco regulatório proposto, para que não percamos outra oportunidade. 


\section{BIBLIOGRAFIA}

Agência Nacional do Petróleo, Gás Natural e Biocombustíveis ANP. Notas e Estudos Técnicos. Disponível em: $<$ <ttp://www.anp.gov.br/wwwanp/notas-tecnicas>. Acesso em 15 de outubro de 2017.

Agência Nacional do Petróleo, Gás Natural e Biocombustíveis ANP. Legislação ANP. Disponível em: $<$ http://nxt.anp.gov.br/NXT/gateway.dll?f=templates \&fn=default.htm\&vid =anp:10.1048/enu>. Acesso em 17 de outubro de 2017.

ALMEIDA, Edmar; FERRARO, Marcelo. Indústria do gás natural: fundamentos técnicos e econômicos. 1 ed. Rio de Janeiro: Synergia, 2013.

ARAGÃO, Alexandre Santos De. Direito do petróleo e de outras fontes de energia. 1 ed. Rio de Janeiro: Lumen Juris, 2011.

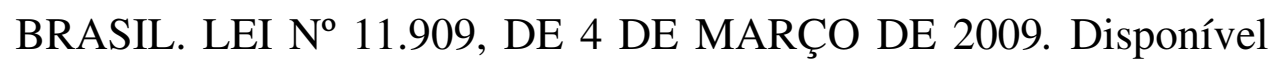
em: $<$ http://www.planalto.gov.br/ccivil_03/_Ato20072010/2009/Lei/L11909.htm >. Acesso em 10 de outubro de 2017.

. DECRETO-LEI No 395, DE 29 DE ABRIL DE 1938.

Disponível em: <http://www.planalto.gov.br/ccivil_03/Decreto-Lei/19371946/Del0395.htm>. Acesso em 10 de outubro de 2017.

. LEI N 2.004, DE 3 DE OUTUBRO DE 1953. Disponível

em: <http://www.planalto.gov.br/ccivil_03/LEIS/L2004.htm>. Acesso em 10 de outubro de 2017.

. Constituição da República Federativa do Brasil de 1988.

Disponível

em:

$<$ http://www.planalto.gov.br/ccivil_03/Constituicao/Constituicao.htm>. Acesso em 10 de outubro de 2017. 
. Emenda Constitucional No 9, de 09 de Novembro de 1995.

Disponível

em:

<http://www.planalto.gov.br/ccivil_03/Constituicao/Emendas/Emc/emc09.h tm\#art3>. Acesso em 11 de outubro de 2017.

LEI N 9.478, DE 6 DE AGOSTO DE 1997. Disponível

em: <https://www.planalto.gov.br/ccivil_03/Leis/L9478.htm>. Acesso em 11 de outubro de 2017.

. DECRETO No 3.520, DE 21 DE JUNHO DE 2000.

Disponível

em:

<http://www.planalto.gov.br/ccivil_03/decreto/D3520.htm>. Acesso em 12 de outubro de 2017.

Confederação Nacional da Indústria. Reestruturação do setor de gás natural: uma agenda regulatória - Brasília: CNI, 2016.

Comissão de Minas e Energia. Substitutivo ao Projeto de Lei No 6.407, de 2013. Disponível em: <http://www.abegas.org.br/Site/wpcontent/uploads/2017/10/Nova-lei-do-g\%C3\%A1s-natural_16-Outubro2017.pdf>. Acesso em 28 de outubro de 2017.

GOMES, Ieda; HOLLANDA, Lavinia; MUÑOZ, Camilo; QUINTELLA, Carlos. Cadernos FGV Energia. Novembro 2014, Ano 1, ${ }^{\circ}$ 2 , ISSN $2358-5277$.

MARQUES, Fernando; PEREIRA, Sergio. Gás natural e transição para uma economia de baixo carbono. 1 ed. Rio de Janeiro: Synergia, 2015 .

Ministério de Minas e Energia - MME. Gás para Crescer Relatório Técnico - versão beta - Outubro/2016. Disponível em: <http://www.mme.gov.br/documents/10584/4006960/0+G\%C3\%A1s+para 
+Crescer_Relat\%C3\%B3rio+T\%C3\%A9cnico.pdf/92738252-2868-4394a9fc-b6f4fd9e6bc7>. Acesso em 21 de outubro de 2017.

- Plano Decenal de Expansão de Energia 2024. Disponível em: $<$ http://www.epe.gov.br/PDEE/Relat\%C3\%B3rio\%20Final\%20do\%20PDE $\% 202024$.pdf $>$. Acesso em 21 de outubro de 2017.

- MME abre consulta sobre diretrizes propostas pelo Gás para Crescer. Disponível em: <http://www.mme.gov.br/web/guest/pagina-inicial/outras-noticas//asset_publisher/32hLrOzMKwWb/content/mme-abre-consulta-sobrediretrizes-propostas-pelo-gas-para-crescer>. Acesso em 21 de outubro de 2017. - Consulta Pública - Gás para Crescer. Disponível em: <http://www.mme.gov.br/web/guest/consultaspublicas?p_p_id=consultapublicaexterna_WAR_consultapublicaportlet\&p_ p_lifecycle $=0 \& p \_p \_s t a t e=$ normal $\&$ p_p_mode $=$ view $\&$ p_p_col_id $=$ column1\&p_p_col_count=1\&_consultapublicaexterna_WAR_consultapublicaportl et_consultaId=20\&_consultapublicaexterna_WAR_consultapublicaportlet_ mvcPath $=\% 2$ Fhtml $\% 2$ Fpublico $\% 2$ FdadosConsultaPublica.jsp $>$. Acesso em 21 de outubro de 2017.

NETO, Artur Watt. Petróleo, gás natural e biocombustíveis: doutrina, jurisprudência e legislação. 1 ed. São Paulo: Saraiva, 2014.

Population Reference Bureau. Human Population: Population Growth - World Population Growth, 1950-2050. Disponível em: $<$ http://www.prb.org/Publications/Lesson-

Plans/HumanPopulation/PopulationGrowth.aspx>. Acesso em 25 de outubro de 2017. 
ROSADO, Marilda. Direito do petróleo. 3 ed. Rio de Janeiro: Renovar, 2014. p. 591.

Terciotti Advogados. Substitutivo do PL do Gás é finalizado e já pode receber contribuições. Disponível em: $<$ http://terciotti.com.br/news/substitutivo-do-pl-do-gas-e-finalizado-e-japode-receber-contribuicoes/>. Acesso em 28 de outubro de 2017. 